University of Wisconsin Milwaukee

UWM Digital Commons

Geosciences Faculty Articles

Geosciences

3-16-2010

\title{
Paleointensity estimates from ignimbrites: An evaluation of the Bishop Tuff
}

Jeffrey S. Gee

University of California - San Diego, jsgee@ucsd.edu

Yongjae $\mathrm{Yu}$

Chungnam National University

Julie A. Bowles

University of Wisconsin-Milwaukee, bowlesj@uwm.edu

Follow this and additional works at: https://dc.uwm.edu/geosci_facart

Part of the Earth Sciences Commons

\section{Recommended Citation}

Gee, Jeffrey S.; Yu, Yongjae; and Bowles, Julie A., "Paleointensity estimates from ignimbrites: An evaluation of the Bishop Tuff" (2010). Geosciences Faculty Articles. 12.

https://dc.uwm.edu/geosci_facart/12

This Article is brought to you for free and open access by UWM Digital Commons. It has been accepted for inclusion in Geosciences Faculty Articles by an authorized administrator of UWM Digital Commons. For more information, please contact open-access@uwm.edu. 


\title{
Click
Here
for
Full \\ Article
}

\section{Paleointensity estimates from ignimbrites: An evaluation of the Bishop Tuff}

\author{
Jeffrey S. Gee \\ Geosciences Research Division, Scripps Institution of Oceanography, University of California, San Diego, La Jolla, \\ California 92093-0220, USA (jsgee@ucsd.edu) \\ Yongjae Yu \\ Department of Geology and Earth Environmental Sciences, Chungnam National University, Daejeon 305-764, \\ South Korea

\section{Julie Bowles} \\ Department of Geology and Geophysics, University of Minnesota, Minneapolis, Minnesota 55455, USA
}

[1] Ash flow tuffs, or ignimbrites, typically contain fine-grained magnetite, spanning the superparamagnetic to single-domain size range that should be suitable for estimating geomagnetic field intensity. However, ignimbrites may have a remanence of thermal and chemical origin as a result of the complex magnetic mineralogy and variations in the thermal and alteration history. We examined three stratigraphic sections through the $\sim 0.76 \mathrm{Ma}$ Bishop Tuff, where independent information on postemplacement cooling and alteration is available, as a test of the suitability of ignimbrites for paleointensity studies. Thermomagnetic curves suggest that low-Ti titanomagnetite $\left(\mathrm{T}_{\mathrm{c}}=560^{\circ} \mathrm{C}-580^{\circ} \mathrm{C}\right)$ is the dominant phase, with a minor contribution from a higher $\mathrm{T}_{\mathrm{c}}$ phase(s). Significant remanence unblocking above $580^{\circ} \mathrm{C}$ suggests that maghemite and/or (titano)maghemite is an important contributor to the remanence in most samples. We obtained successful paleofield estimates from remanence unblocked between $440^{\circ} \mathrm{C}$ and $580^{\circ} \mathrm{C}$ for 46 of 89 specimens ( 15 sites at two of three total localities). These specimens represent a range of degrees of welding and have variable alteration histories and yet provide a consistent paleofield estimate of $43.0 \mu \mathrm{T}( \pm 3.2)$, equivalent to a VADM of $7.8 \times 10^{22} \mathrm{Am}^{2}$. The most densely welded sections of the tuff have emplacement temperatures inferred to be as high as $\sim 660^{\circ} \mathrm{C}$, suggesting that the remanence may be primarily thermal in origin, though a contribution from thermochemical remanence cannot be excluded. These results suggest that ignimbrites may constitute a viable material for reliable paleointensity determinations.

Components: 9761 words, 8 figures, 1 table.

Keywords: geomagnetic intensity; ash flow.

Index Terms: 1521 Geomagnetism and Paleomagnetism: Paleointensity; 1519 Geomagnetism and Paleomagnetism: Magnetic mineralogy and petrology; 1527 Geomagnetism and Paleomagnetism: Paleomagnetism applied to geologic processes.

Received 9 September 2009; Revised 8 December 2009; Accepted 25 January 2010; Published 16 March 2010.

Gee, J. S., Y. Yu, and J. Bowles (2010), Paleointensity estimates from ignimbrites: An evaluation of the Bishop Tuff, Geochem. Geophys. Geosyst., 11, Q03010, doi:10.1029/2009GC002834. 


\section{Introduction}

[2] The Earth's magnetic field varies both spatially, as well as temporally, in both magnitude and direction. Compared to directional studies, there are far fewer studies of absolute intensity variations of the geomagnetic field. There are only a few hundred cooling units for which absolute paleointensity data are available for the past $300 \mathrm{Ma}$ [Selkin and Tauxe, 2000; Biggin and Thomas, 2003; Valet, 2003], and of these, more than half are from the past $300 \mathrm{ka}$. The scarcity of absolute paleointensity determinations stems from the rareness of geological materials that contain exclusively (or dominantly) singledomain (SD) iron oxides as well as the fact that the magnetic minerals in most rocks alter during the repeated laboratory heat treatments required for the preferred methods of determining intensity.

[3] Several observations suggest that carefully selected samples from ignimbrites should yield reliable estimates of the ancient geomagnetic field intensity. First, and most importantly, fine-grained cubic $\mathrm{Fe}$ oxides spanning the superparamagnetic (SP) to SD size range have been documented in silicic glasses preserved in ash flow tuffs [e.g., Geissman et al., 1983; Schlinger et al., 1991; Worm and Jackson, 1999]. Although coarser grains may also be present, these fine $\mathrm{Fe}$ oxides are thought to crystallize from the glass at elevated temperatures after ignimbrite emplacement and should (dominantly) carry a thermoremanent magnetization (TRM). Second, the fine-grained magnetic minerals in a glassy matrix may be effectively armored from alteration due to exposure to air during the multiple laboratory heatings necessary for a paleofield determination. These characteristics are similar to those in submarine basaltic glass, which has proven a valuable material for estimating ancient field intensity [e.g., Pick and Tauxe, 1993; Mejia et al., 1996; Carlut and Kent, 2000; Bowles et al., 2006]. Finally, ash flow tuffs are typically well suited for high-precision ${ }^{40} \mathrm{Ar} /{ }^{39} \mathrm{Ar}$ dating [e.g., McIntosh et al., 1990; van den Bogaard and Schirnick, 1995; Sarna-Wojcicki et al., 2000] that can provide an accurate age framework for any paleointensity results.

[4] Although the presence of glass-hosted fine grained magnetite provides reason for some optimism, the magnetic mineralogy and thermal history of ignimbrites may be complex. Relatively few studies have used ignimbrites for paleointensity determinations [Reynolds, 1977; Tanaka et al., 1994, 2009; Schnepp, 1995]. Although these authors recognized the poten- tial to obtain paleofield information from ignimbrites, little or no independent information on the thermal and alteration history of the ignimbrites was available and, consequently, the viability of ignimbrites as paleofield recorders is not well documented. As a test of the potential of ash flow tuffs as a geomagnetic intensity recorder we have investigated samples from three stratigraphic sections in the Bishop Tuff. The wealth of previous studies documenting the eruptive and cooling history [e.g., Hildreth, 1979; Wilson and Hildreth, 2003; Sheridan and Wang, 2005] as well as postemplacement alteration [e.g., Sheridan, 1970; Holt and Taylor, 1998] of the Bishop Tuff make it particularly well suited for evaluating the potential of ash flow tuffs as recorders of geomagnetic field intensity.

[5] The Bishop Tuff erupted at $760 \pm 1 \mathrm{ka}$ [van den Bogaard and Schirnick, 1995], accompanying collapse of the Long Valley caldera in eastern California. Approximately $200 \mathrm{~km}^{3}$ of high-silica rhyolite accumulated as outflow sheets that are well exposed throughout the volcanic tablelands north of Bishop, CA (Figure 1), with exposures locally as thick as $170 \mathrm{~m}$ in the Owens River Gorge [Hildreth and Wilson, 2007]. Estimates of the duration of the entire eruptive sequence range from a few days to a few years [cf. Wilson and Hildreth, 1997; Sheridan and Wang, 2005]. Magmatic temperatures increase from about $715^{\circ} \mathrm{C}$ for the earliest eruptive units to $820^{\circ} \mathrm{C}$ in the uppermost units [Hildreth and Wilson, 2007]. Modeling of density profiles in exposures to the north and east of the caldera yields emplacement temperatures that are typically $\sim 650^{\circ} \mathrm{C}$, though values as low as $530^{\circ} \mathrm{C}$ were calculated for some distal deposits $(20-30 \mathrm{~km}$ from the caldera) [Sheridan and Wang, 2005]. The time necessary for the Bishop Tuff to cool to ambient temperatures is not known. Models of ignimbrite cooling suggest that thick ash flow tuffs might remain at temperatures of several hundred of degrees for tens of years, depending on the amount of rainfall [Riehle et al., 1995]. Decadal-scale cooling is also supported by evidence that a hot, densely welded zone persists at depth in the 1912 Novarupta pyroclastic flow [Hogeweg et al., 2005]. It appears reasonable that remanence in the Bishop Tuff was acquired over a comparable time scale of years to decades.

\section{Magnetism of Ash Flow Tuffs}

[6] The nature and origin of remanence in ash flows will be affected by the emplacement temperature and cooling history as well as by postemplacement 


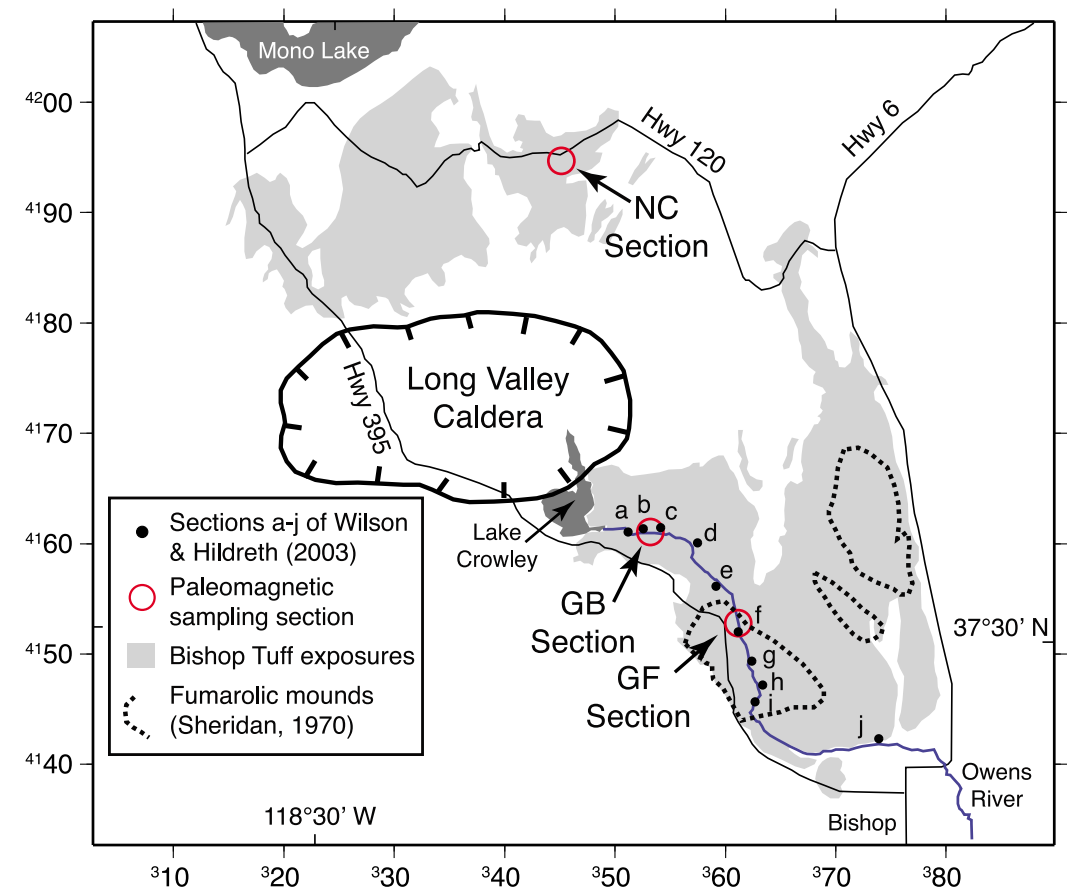

Figure 1. Location of paleomagnetic sampling sections in the Bishop Tuff. Coordinates are UTM easting and northing (times $1000 \mathrm{~m}$ ) values. Gorge section F (GF), location 4152780, 361155; gorge section B (GB), location 4161074, 353191; North Canyon (NC), location 4194666, 345129. The locations of sections from Wilson and Hildreth [2003] and the approximate outlines of fumarole zones [Sheridan, 1970] are shown for reference. Bishop Tuff outcrop pattern after Wilson and Hildreth [1997].

processes that can include precipitation of new magnetic phases and alteration of existing magnetic minerals. For example, a sample might be expected to acquire a thermoremanence (TRM) if the emplacement temperature is above the Curie point $\left(T_{c}\right)$ of the dominant magnetic phase and a partial TRM (pTRM) if emplacement occurs below $\mathrm{T}_{\mathrm{c}}$. The temperature at which this pTRM is removed has proven useful in estimating the emplacement temperature of distal deposits [Hoblitt and Kellog, 1979; Kent et al., 1981; McClelland and Druitt, 1989; Bardot and McClelland, 2000; McClelland et al., 2004]. Alternatively, if glass-hosted Fe-Ti oxides nucleate and grow at $\mathrm{T}<\mathrm{T}_{\mathrm{c}}$ or if alteration produces new magnetic phases below their Curie temperatures, a thermochemical remanence (TCRM) will be acquired.

[7] The emplacement temperature is perhaps the most critical factor in evaluating the nature of the remanence in ash flow deposits. Although intracaldera and near-source outflow sheets may be emplaced at temperatures approaching the liquidus temperature $\left(\sim 700^{\circ} \mathrm{C}\right.$ to $\left.>900^{\circ} \mathrm{C}\right)$, more distal deposits, or flows where significant mixing with air occurs, may be emplaced at considerably lower temperatures. For example, the directed blast deposits of the 18 May 1980 eruption at Mount St. Helens were emplaced at $\sim 100^{\circ} \mathrm{C}$, while subsequent ash flows were deposited at temperatures ranging from $850^{\circ} \mathrm{C}$ to less than $400^{\circ} \mathrm{C}$ [Banks and Hoblitt, 1981, 1996]. Near isothermal temperature profiles measured in these deposits shortly after eruption reflect the emplacement temperature, with progressively more curved (conductive) cooling profiles developing over a period of days to weeks [Banks and Hoblitt, 1996].

[8] The density and degree of welding can provide a proxy for the thermal history of ancient deposits [Riehle et al., 1995; Wilson and Hildreth, 2003; Sheridan and Wang, 2005]. After emplacement, pyroclastic deposits can compact and flatten by slow, viscous deformation above the glass transition temperature $\left(\mathrm{T}_{\mathrm{g}}\right.$, the temperature at which a melt transitions from liquid-like behavior to a metastable, glass-like behavior). Below $\mathrm{T}_{\mathrm{g}}$, welding and deformation are greatly inhibited because viscosity increases to the point where time scales of viscous relaxation are greater than the time scales of cooling [e.g., Russell and Quane, 2005; Giordano et al., 2005]. The degree of welding is therefore an indication of the thermal history (and load related to ignimbrite thickness), with the most dense welding 
developed in sections that spent more time at higher temperatures.

[9] Minimum temperature estimates for welding vary from $\sim 550^{\circ} \mathrm{C}$ [Sheridan and Ragan, 1976] to over $600^{\circ} \mathrm{C}$ [Riehle, 1973; Grunder et al., 2005] and approximately coincide with both the glass transition temperature and the Curie temperature for magnetite. Welding may occur at slightly lower temperatures for very slow cooling or if the matrix glass has significant water [Russell and Quane, 2005; Deubener et al., 2003; Giordano et al., 2005]. Although the preeruptive magma may contain 46 wt $\% \mathrm{H}_{2} \mathrm{O}$ [Dunbar and Hervig, 1992; Anderson et al., 2000], much of this magmatic water is likely lost on eruption. For example, juvenile products from the Mount St. Helens pyroclastic deposits have $\mathrm{H}_{2} \mathrm{O}$ contents ranging from $0.1 \%$ to $0.5 \%$ [Lipman et al., 1981]. Thus, significant welding is indicative of emplacement temperatures near or above the Curie point of magnetite, and the resulting remanence should dominantly be thermal in origin providing the magnetite is initially present or is produced at high temperature.

[10] The remanence of ash flows may be significantly affected by the nucleation and growth of fine-grained magnetite in the glassy matrix after emplacement. The postemplacement origin is convincingly demonstrated by systematic variations in microcrystal size, susceptibility, and remanence with height above the base of the ash flow, as well as reheating experiments of glass shards [Schlinger et al., 1991]. Glass-hosted microcrystals with a size near the stable single-domain range have been documented in several ash flow tuffs [Schlinger et al., 1988a, 1988b, 1991; Rosenbaum, 1993; Worm and Jackson, 1999], and they may dominate the bulk magnetic properties as well as the natural remanence.

[11] The temperature of microcrystal precipitation and growth is not well constrained, but a reasonable lower-temperature limit may be the glass transition temperature $\left(\mathrm{T}_{\mathrm{g}}\right)$ of the tuff matrix. Schlinger et al. [1991] estimate the formation temperature to be $>500^{\circ} \mathrm{C}$ based on reheating experiments of ash flow glass shards. Significant nucleation and growth of FeTi oxides also appears to be limited to temperatures above $\mathrm{T}_{\mathrm{g}}$ in basaltic and calc-alkaline glasses [Worm and Markert, 1987; Pick and Tauxe, 1994; Bowles et al., 2008]. If $\mathrm{T}_{\mathrm{g}}$ is below the Curie temperature of the precipitated microcrystals, they are likely to carry a TCRM acquired in the interval $\mathrm{T}_{\mathrm{g}}<\mathrm{T}<\mathrm{T}_{\mathrm{c}}$. Below $\mathrm{T}_{\mathrm{g}}$, the remanence acquired during initial cooling or later unblocked in the lab should be a pure (albeit partial) TRM.

[12] Postemplacement vapor phase alteration and associated fumarole development and devitrification in ash flows may significantly modify the magnetic mineralogy. The products of vapor phase alteration, often occurring as precipitates in cavities or as encrusting coatings, may include magnetite as well as lower-temperature phases such as goethite and hematite [e.g., Keith and Muffler, 1978; Keith, 1991]. Although early studies postulated that the vapor was derived from devitrification and the associated crystallization of anhydrous phases [Sheridan, 1970], subsequent oxygen isotopic studies indicate that exchange is predominantly with meteoric water, with an initial, short-lived high-temperature $\left(>500^{\circ} \mathrm{C}\right)$ alteration followed by more protracted exchange at lower temperature $\left(<150^{\circ} \mathrm{C}\right)$ [Holt and Taylor, 1998, 2001].

[13] Although vapor phase alteration undoubtedly contributes to the complexities in the magnetic mineralogy of ash flows [e.g., Rosenbaum, 1993; Schlinger et al., 1991; Palmer et al., 1996], these effects are likely to be spatially limited. For example, fumarolic cracks in the 1912 ash flow at the Valley of Ten Thousand Smokes are typically narrow and can be traced only meters into the tuff and are accompanied by meter-scale zonations from leached to unaltered tuff [Holt and Taylor, 2001; Keith, 1991]. Similarly, devitrification [Sheridan, 1970] and oxygen isotope depletions [Holt and Taylor, 1998] are minimal outside of the morphological limit of fumarole mounds in the Bishop Tuff. The low permeability of welded units may further limit the diffusion of vapor [Keating, 2005], and is observed to serve as a lower limit of fumarolic activity in the Bishop Tuff [Holt and Taylor, 1998].

[14] Variations in the magnetic mineralogy, thermal history and postemplacement alteration of ignimbrites will likely complicate the interpretation of paleointensity data from ash flow deposits. In this paper, we examine variations in magnetic mineralogy, remanence and paleointensity estimates from three stratigraphic sections through the Pleistocene Bishop Tuff. These samples represent a range of thermal and alteration histories and the internal consistency of paleointensity results that we report here suggests that carefully selected samples from ash flow tuffs may provide a reliable record of ancient field intensity. Paleointensity studies in historic ash flows, where the geomagnetic field intensity is known, may provide a more robust 
validation of the reliability of paleofield estimates from ignimbrites.

\section{Sampling Profiles in the Bishop Tuff}

[15] We sampled three stratigraphic sections (GB and GF in the Owens River gorge and the $\mathrm{NC}$ section north of the caldera (Figure 1)) that span a range of degrees of welding and intensity of alteration. A total of 39 oriented block samples were collected from the three stratigraphic sections and 262 cores were drilled from these blocks for remanence measurements. Densities were determined for each block sample as a proxy for the degree of welding and thermal history (Figure 2 and Data Set S1). ${ }^{1}$ Our density estimates, obtained from the mass and volume estimated using Archimedes principle, have significant uncertainties (particularly for poorly welded samples in the GB section) but nonetheless were sufficient to correlate with more accurate, previously published density profiles for the sampled sections. Our measured stratigraphic thicknesses differ by as much as $15 \%$ from those previously published, which were adjusted to match our measured sections. For each stratigraphic section, we also measured susceptibility variations (at $\sim 1 \mathrm{~m}$ interval) using a portable SM-20 susceptibility meter. These readings were calibrated using susceptibilities from core samples measured on a Kappabridge KLY-2 (Data Set S1) and the resulting susceptibility profiles provide a first-order indication of changes in magnetic mineralogy.

[16] Section GF is located within the fumarole zone mapped by Sheridan [1970] but is not coincident with any major fumarolic feature [Holt and Taylor, 1998]. The section is located along a steep trail on the west side of the Owens River gorge, apparently coincident with the oxygen isotope sampling profile (site CG) of Holt and Taylor [1998] and at the approximate location of section $\mathrm{F}$ of Wilson and Hildreth [2003]. Based on a detailed study of ten stratigraphic profiles (labeled a-j in Figure 1), Wilson and Hildreth [2003] documented the imbricate nature of eruptive packages exposed in the gorge as well as four distinct welding zones defined by density maxima. Section GF comprises approximately $100 \mathrm{~m}$ of moderately to densely welded eruptive package Ig1Eb overlain by $\sim 40 \mathrm{~m}$ of package Ig2Eb (Figures 2a and 2b) [Wilson and Hildreth, 2003]. Holt and Taylor [1998] documented an interval approximately $40 \mathrm{~m}$ thick with

\footnotetext{
${ }^{1}$ Auxiliary materials are available at $\mathrm{ftp} / / \mathrm{ftp}$.agu.org/apend/gc/ $2009 \mathrm{gc} 002834$.
}

depleted $\delta^{18} \mathrm{O}$ values, and associated with pervasive devitrification of the tuff, above the densely welded tuff. These authors found no evidence for meteoric hydrothermal alteration in the underlying densely welded tuff. The top of this densely welded zone presumably lies at about $80 \mathrm{~m}$ in our section, with the depleted oxygen isotope interval extending through the uppermost part of package $\operatorname{Ig} 1 \mathrm{~Eb}$ and the lowermost part of Ig2Eb (Figures $2 \mathrm{a}$ and $2 \mathrm{~b}$ ).

[17] Section GB was collected along the northern slope of the gorge outside of the mapped fumarole zone (Figure 1), near section B of Wilson and Hildreth [2003] and approximately $2 \mathrm{~km}$ east of site CR of Holt and Taylor [1998]. We sampled only the lower part of the tuff, with our highest samples below the density maximum of welding zone B of Wilson and Hildreth [2003] (Figures 2e and $2 \mathrm{f}$ ). In addition to a $\sim 1 \mathrm{~m}$ thick air fall at about $70 \mathrm{~m}$ in this section (presumably corresponding to fall deposit F6 [Wilson and Hildreth, 1997, 2003]) we identified a second, thinner air fall deposit approximately $20 \mathrm{~m}$ lower in section GB. Oxygen isotopic variations at nearby site $\mathrm{CR}$ reveal magmatic $\delta^{18} \mathrm{O}$ values except for a narrow zone above the densely welded portion of eruptive package Ig1Eb and above our stratigraphically highest sample [Holt and Taylor, 1998]. Although based on quite sparse sampling, the oxygen isotopic data suggest that samples from our GB section may not have experienced significant vapor phase alteration. Magnetic mineralogy data, however, suggest that the unwelded to poorly welded section sampled here may have a more complicated alteration history (see below).

[18] Section NC (North Canyon) lies approximately $15 \mathrm{~km}$ north of the caldera (Figure 1) and is coincident with a density profile (section 45 ) measured by Sheridan and Wang [2005]. This section includes $\sim 45 \mathrm{~m}$ of tuff that is distinctly richer in lithic fragments near the base that we correlate with eruptive package Ig2 $\mathrm{Na}$ and a thinner overlying package that we tentatively identify as Ig2Nb (Figures 2i and 2j) [Hildreth and Wilson, 2007; Wilson and Hildreth, 1997]. Modeling of the density variations suggests that this section comprises three cooling units, with emplacement temperatures ranging from $623^{\circ} \mathrm{C}$ to $666^{\circ} \mathrm{C}$ [Sheridan and Wang, 2005]. Although no oxygen isotopic data are available for this section, whitened intervals at 60 $64 \mathrm{~m}$ and at the top of the section $(>75 \mathrm{~m})$ may reflect alteration.

[19] Emplacement temperatures for the two sections in Owens River Gorge are not available. 

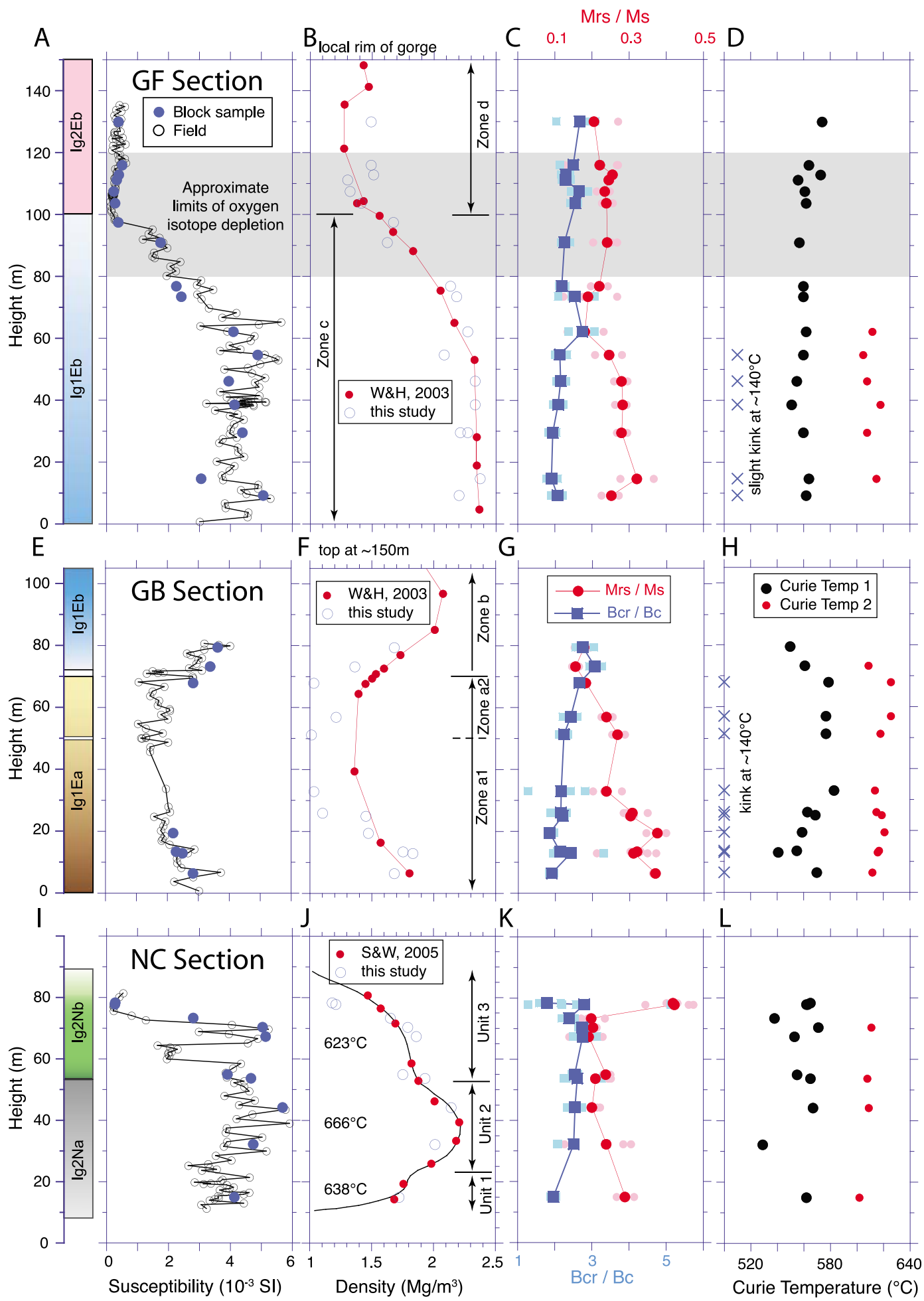

Figure 2. Stratigraphy and magnetic properties for sampling sections (a-d) GF, (e-h) GB, and (i-l) NC in Bishop Tuff. Eruptive units at left after Wilson and Hildreth [2003] and Hildreth and Wilson [2007]. Density data, cooling units, and emplacement temperatures for NC section are from Sheridan and Wang [2005]. Density data for GB and GF sections [Wilson and Hildreth, 2003] have been used to identify tentative cooling units. Figures 2c, 2g, and $2 \mathrm{k}$ show hysteresis data for three to four chips (small, lighter color symbols) and site mean (larger symbols). Figures $2 \mathrm{~d}$, $2 \mathrm{~h}$, and $2 \mathrm{l}$ show Curie temperatures for dominant magnetic phase (Curie temperature 1) and higher-temperature phase (Curie temperature 2). Horizontal gray bar in GF shows approximate location of oxygen isotopic depletion from Holt and Taylor [1998]. 
Density variations from the GF and GB sections, however, allow qualitative estimates to be made by analogy with thermal modeling results. The densely welded lower part of the GF section has densities of $2.3-2.4 \mathrm{~g} / \mathrm{cc}$ and these densities are relatively constant for the bottom $50 \mathrm{~m}$ of the section. The thermal modeling results of Riehle et al. [1995] suggest that for a simple cooling unit, such high densities are achieved only for thick flows emplaced at temperatures of $\sim 660^{\circ} \mathrm{C}$. Slightly lower temperatures (but still $>600^{\circ} \mathrm{C}$ ) are implied for the upper cooling unit in the GB section, with a thickness $\sim 80 \mathrm{~m}$ and a maximum density of $\sim 2.1 \mathrm{~g} / \mathrm{cc}$ [Wilson and Hildreth, 2003]. The low density and lack of a density peak of the upper cooling unit of section GF and the lower cooling unit(s) of section GB preclude the estimation of emplacement temperature, though these temperatures were presumably lower.

\section{Magnetic Mineralogy}

[20] Hysteresis loops were measured for at least three chips from each block sample and a high field ( $\sim 0.1 \mathrm{~T})$ thermomagnetic curve was measured for at least one of these specimens. Together with susceptibility, remanent intensity and unblocking temperature spectra (from the Thellier experiments described below), these data provide information on the magnetic mineralogy and grain size. Hysteresis loops were measured to a peak field of $1 \mathrm{~T}$ on a Princeton Measurements Corporation alternating gradient force magnetometer. Values of saturation magnetization $\left(M_{S}\right)$, saturation remanence $\left(M_{r s}\right)$, and coercive force $\left(B_{c}\right)$ were determined after nonferrimagnetic slope correction. Values of remanence coercivity $\left(B_{c r}\right)$ were obtained from back-field measurements.

[21] The hysteresis ratios for specimens from the Bishop Tuff, as with many natural samples, plot primarily within the pseudo-single-domain (PSD) field on a Day plot (Figure 3). Samples within this PSD region cannot be uniquely interpreted, as such hysteresis ratios may result from a variety of mixtures [e.g., Dunlop, 2002]. The shapes of individual loops may provide more useful information. Although many specimens have undistorted PSD loops (Figure 3a), several specimens have loops that are broadened in the low-field region (termed potbelly loops by Tauxe et al. [1996]). These potbelly loops (Figure 3b) may be modeled as mixtures of SD and SP populations [Tauxe et al., 1996]. Some specimens from the top of the GF and NC sections have wasp-waisted hysteresis loops (extreme example in Figure 3c), indicating a mixture of two distinct coercivity fractions. Many of these samples do not saturate at $1 \mathrm{~T}$, as determined from the difference between the upper and lower branches of the hysteresis loop, suggesting the presence of (titano)hematite in addition to a lower-coercivity phase.

[22] Thermomagnetic curves were measured on a horizontal Curie balance in air with heating/cooling at $50^{\circ} \mathrm{C} \mathrm{min}{ }^{-1}$. All samples have the most significant loss of moment at a temperature near the Curie temperature of magnetite (Figure 4). This dominant Curie temperature $\left(T_{c} 1\right)$ was calculated from the heating curve using the extrapolation method of Moskowitz [1981]. Where a significant magnetization remained above $580^{\circ} \mathrm{C}$, a higher Curie temperature $\left(\mathrm{T}_{\mathrm{c}} 2\right)$ was estimated using the method of intersecting tangents [Grommé et al., 1969].

[23] Because this higher-temperature contribution can be subtle, we use plots of the first derivative (Figure 5) as an aid in identifying its presence. For a sample with magnetite as the sole magnetic phase, the first derivative will be approximately zero above $580^{\circ} \mathrm{C}$ (e.g., GF8-3 in Figure 5). Any higher-temperature phase should be evident as a break in slope in the derivative plot (compare GF07-3 in Figures 4d and 5) or a secondary peak in the derivative plot if this phase is more significant (compare GB09-1 in Figures 4b and 5). Although noise may obscure these features in samples with low magnetic moments, the first derivative provides a reasonably objective way to determine whether such higher-temperature phases are present.

[24] The rock magnetic and remanence data allow us to subdivide the samples into three groups based on their magnetic mineralogy. These groups are also broadly correlated with the stratigraphic and cooling units. The first group (Type A) is found at the top of the GF section (stratigraphic unit Ig2Eb) and the top of the NC section (above $\sim 77 \mathrm{~m}$ ). These poorly welded samples are characterized by low susceptibility (Figure 2) and low remanent magnetization. Type A samples have a single Curie temperature at $\sim 560^{\circ} \mathrm{C}-580^{\circ} \mathrm{C}$, suggesting the presence of magnetite. However, a significant fraction (up to $\sim 25 \%$ ) of the NRM unblocks between $580^{\circ} \mathrm{C}$ and $640^{\circ} \mathrm{C}-660^{\circ} \mathrm{C}$, indicating the presence of a secondary higher $\mathrm{T}_{\mathrm{c}}$ fraction; we presume this fraction includes (titano)hematite, based on the high coercivity of these samples (e.g., Figure 3c). The higher Curie temperature may be masked by noise 

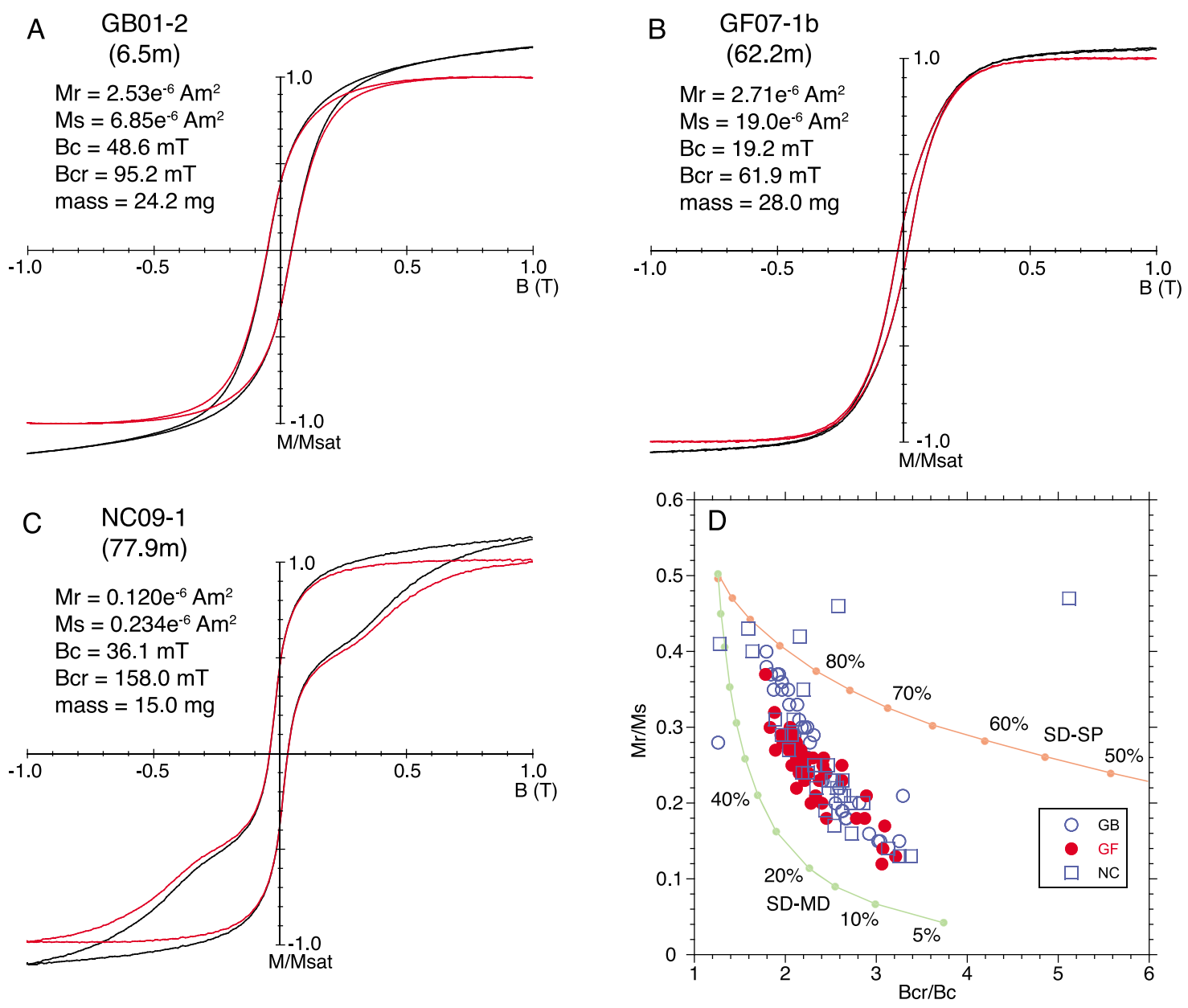

Figure 3. $(a-c)$ Representative hysteresis data and (d) summary hysteresis parameters for Bishop Tuff samples. For hysteresis loops, the original curve is shown in black, and the high field slope-corrected (typically $0.7-1.0 \mathrm{~T}$; 0.851.0 T for NC09-1) curve is shown in red. In Figure 3d the magnetite mixing trends and percentage of single-domain (SD) material for SD-SP and SD-MD (multidomain) from Dunlop [2002] are shown for reference. Note that these trends are not applicable for some specimens plotted in Figure 3d that have mixtures of high- and low-coercivity phases.

in the thermomagnetic data for these weak samples (Figure 4f).

[25] More densely welded samples from the lower part of section GF and top of section GB (both in stratigraphic unit $\operatorname{Ig} 1 \mathrm{~Eb}$ ) and the lower part of section NC (below $\sim 76 \mathrm{~m}$ ) constitute a second group (Type B). These samples have approximately reversible thermomagnetic curves (e.g., Figures $4 \mathrm{c}-4 \mathrm{e}$ ), a dominant $\mathrm{T}_{\mathrm{c}}$ typically between $550^{\circ} \mathrm{C}$ and $580^{\circ} \mathrm{C}$, and frequently include a second phase with a $\mathrm{T}_{\mathrm{c}}$ between $600^{\circ} \mathrm{C}$ and $620^{\circ} \mathrm{C}$ (Figures 4 and 5). In contrast to Type A samples, hysteresis loops of Type B samples show no evidence of a distinct high-coercivity phase and remanent intensities are significantly higher. Type B samples may also have significant unblocking above $580^{\circ} \mathrm{C}$. These high unblocking temperatures may be related to thermally stable maghemite [cf. Palmer et al., 1996] although we cannot exclude the presence of (titano)hematite. Several samples from the lower part of the GF section have a very slight inflection or kink in the thermomagnetic curve at $\sim 140^{\circ} \mathrm{C}$ (a feature similar to that in the third sample type discussed below).

[26] Samples from stratigraphic unit Ig1Ea in section GB have a distinctive thermomagnetic behavior that we designate as a third group (Type C). These poorly welded samples are similar to Type B in that they have hysteresis loops that saturate by $1 \mathrm{~T}$ and most have two Curie temperatures, consistent with a low-Ti magnetite in addition to maghemite. In contrast to Type B samples, Type C samples have a moderate to very pronounced increase or kink in the warming curve at $\sim 140^{\circ} \mathrm{C}$, as well as an inflection 

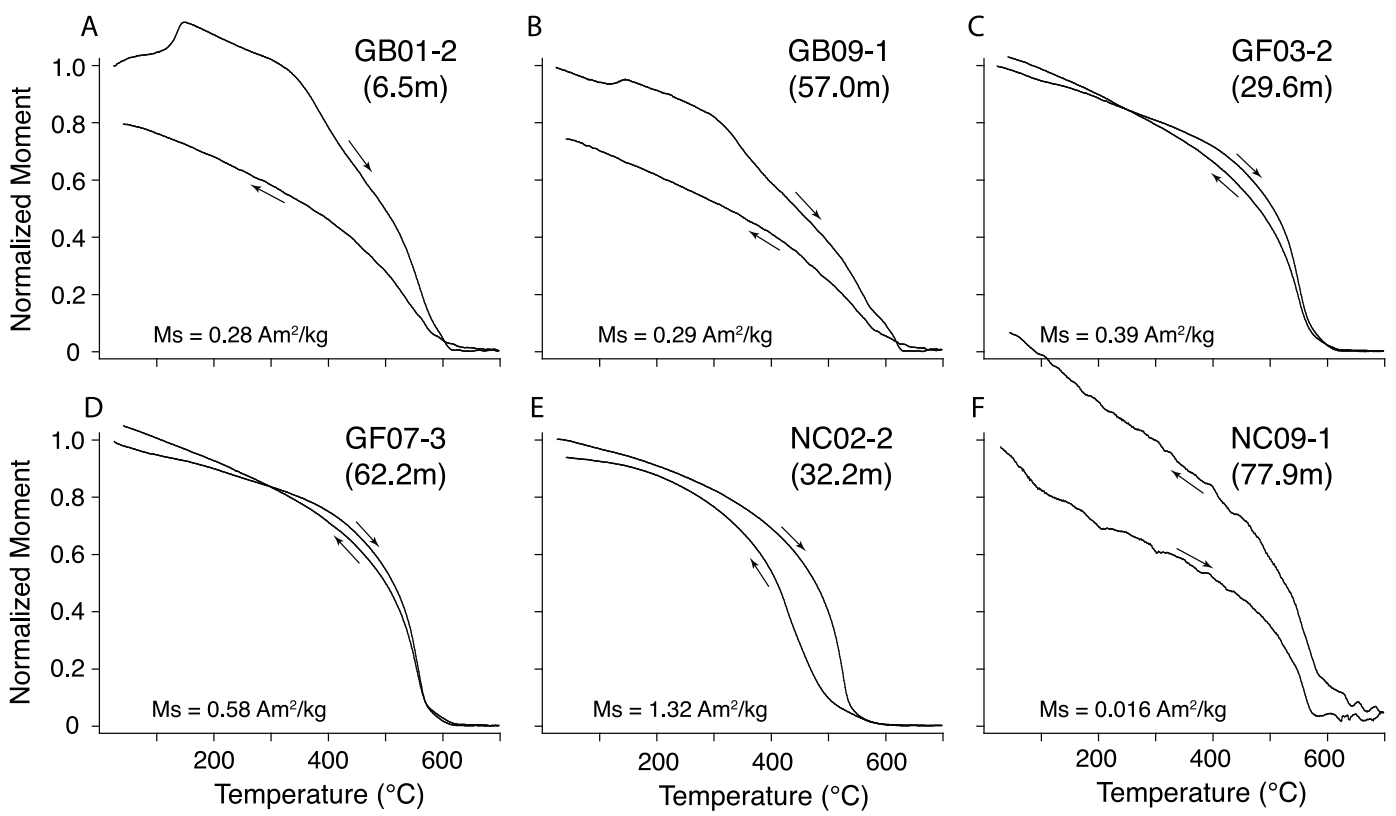

Figure 4. Representative thermomagnetic curves from Bishop Tuff samples. All data were acquired in air at a heating rate of $50^{\circ} \mathrm{C} \mathrm{min}^{-1}$. Saturation magnetization values are from hysteresis data for the same chips.

between $\sim 360^{\circ} \mathrm{C}-420^{\circ} \mathrm{C}$ (Figures $4 \mathrm{a}, 4 \mathrm{~b}$, and 5). Both these features are absent in the cooling curve, suggesting the presence of one or more metastable phases. The much lower moment on the cooling curve is consistent with conversion of maghemite to hematite. The origin of the kink in the warming curve is not well understood. However, this feature is similar to that of thermomagnetic curves from hydrothermally altered lavas [Ade-Hall et al., 1971] and may reflect the effects of hydrothermal alteration.

\section{Paleointensity Results}

[27] There are many laboratory protocols for determining absolute paleointensity from geological and archeological materials. The method widely considered to be the most reliable is a double heating, Thellier-type paleointensity determination [Thellier and Thellier, 1959], which relies on the principles of additivity, independence, and reciprocity of pTRMs. In this study, we used the IZZI variant $[Y u$ et al., 2004; Yu and Tauxe, 2005] which alternates the order in which the in-field and zero-field treatments are applied and has the advantage of highlighting incomplete removal of pTRM without additional heating steps for pTRM tail checks. Double heatings (in air) were carried out to a maximum temperature of $600^{\circ} \mathrm{C}$ for most specimens, but with additional steps to a maximum of $660^{\circ} \mathrm{C}$ for specimens with significant remanence remaining after heating to $600^{\circ} \mathrm{C}$. A laboratory field of $25 \mu \mathrm{T}$ was used for the in-field steps.

[28] Paleointensity experiments were conducted on a total of 89 specimens, with more than half of these (46) yielding successful (as defined by the selection criteria discussed below) ancient field estimates (Figures 6a-6d). No successful paleointensity estimates were obtained from the GB section. All pilot specimens from this section showed pronounced convex downward Arai plots [Nagata et al., 1963] and typically had positive pTRM checks (Figure 6e); this suggests abundant, nonuniformly magnetized coarse-grained $\mathrm{Fe}$ oxides. The other type of rejected samples includes failure in pTRM checks (Figure 6f).

[29] Because samples from the Bishop Tuff may contain a variety of magnetic phases, we have calculated absolute paleointensities for a range of temperature intervals. The lowest-temperature interval (labeled L in Data Set S2) was from $440^{\circ} \mathrm{C}$ to $580^{\circ} \mathrm{C}$ (or $570^{\circ} \mathrm{C}$ if the specimen was not heated at $580^{\circ} \mathrm{C}$ ). All specimens were heated to at least $600^{\circ} \mathrm{C}$ and most specimens had significant (from $\sim 10 \%$ to $45 \%$ ) remanence remaining at $580^{\circ} \mathrm{C}$. We calculated additional paleofield estimates at highertemperature intervals in order to evaluate whether phases with higher unblocking temperatures gave similar paleofield estimates as the low-temperature component that is presumably carried by magnetite. For specimens heated to only $600^{\circ} \mathrm{C}$, we calculated 

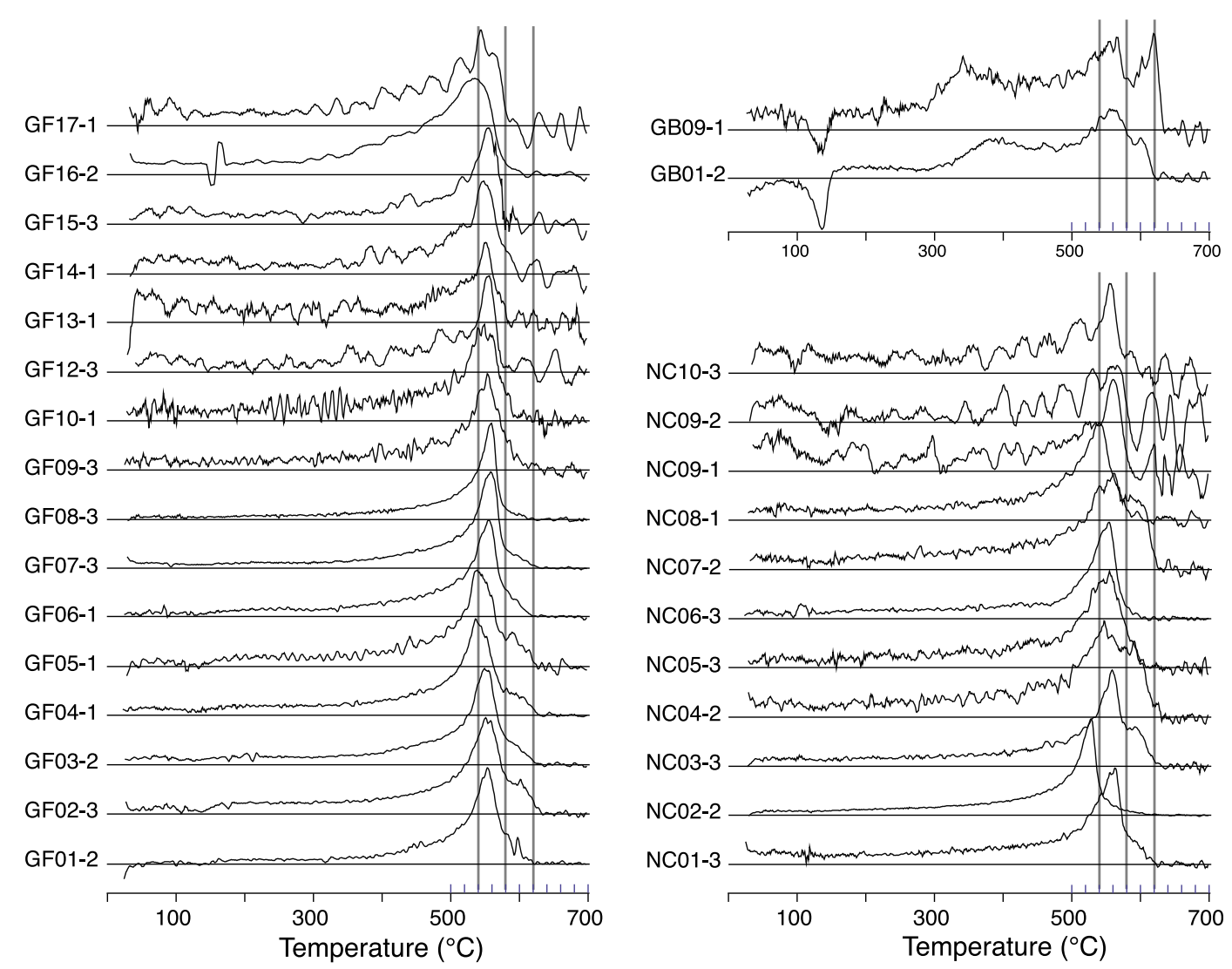

Figure 5. Stratigraphic variation of first derivative of thermomagnetic curves for Bishop Tuff samples. All specimens from the GF and NC sections are shown. Only two representative curves for the GB section are shown as no paleointensity data were obtained from this section. Values above the horizontal zero level lines correspond to negative derivatives. The vertical gray lines are at $540^{\circ} \mathrm{C}, 580^{\circ} \mathrm{C}$, and $620^{\circ} \mathrm{C}$. Derivatives were calculated from data smoothed by a five-point running mean except for the weak samples (GF12-3 to GF17-1 and NC09-1 to NC10-3), which were smoothed by an 11-point running mean.

the paleofield from the expanded temperature range $440^{\circ} \mathrm{C}$ to $600^{\circ} \mathrm{C}$ (labeled E in Data Set S2). For specimens heated to $660^{\circ} \mathrm{C}$, we calculated the paleofield from $580^{\circ} \mathrm{C}$ to $660^{\circ} \mathrm{C}$ (labeled $\mathrm{H}$ in Data Set S2) and from $440^{\circ} \mathrm{C}$ to $660^{\circ} \mathrm{C}$ (labeled A in Data Set S2).

[30] A significant fraction of the specimens yield linear Arai plots (NRM remaining versus pTRM gained (Figures 6a-6d)) over one or more of the temperature intervals noted above. Apparent paleofield intensity values calculated from the different temperature intervals range from $11 \mu \mathrm{T}$ to $\sim 111 \mu \mathrm{T}$ (Data Set S2 and Figure 7c). Several criteria for assessing the reliability of Thellier paleointensity experiments have been developed [e.g., Coe et al., 1978; Selkin and Tauxe, 2000]. We use the cumulative distribution functions (CDFs) for various reliability parameters to provide a reasonably objective method of evaluating the paleointensity results (Figure 7).
[31] Examination of several possible reliability criteria reveals that the most extreme paleointensity values can be filtered out using only two parameters: an estimate of the scatter about the best fit line normalized by the slope $(\sigma / \mid \mathrm{bl}$ [York, 1968]) and the maximum deviation of the pTRM check normalized by the length of the best fit line (DRAT [Selkin and Tauxe, 2000]). Selecting an arbitrary cutoff of $\sigma / \mid \mathrm{bl} \leq 0.05$ for the former removes approximately 80 of the 180 initial paleofield estimates (note that each specimen yields 2 or 3 initial estimates corresponding to the temperature intervals noted above). Requiring a DRAT value $<5$ results in the rejection of an additional 21 paleofield estimates. Examination of the distribution of paleointensity values (Figure 7c) provides some justification for these cutoff values for DRAT and $\sigma / \mathrm{lbl}$. All paleointensity estimates above $50 \mu \mathrm{T}$ have $\sigma / \mathrm{lbl}$ values $>0.1$ and these high values are predominantly associated with 
A

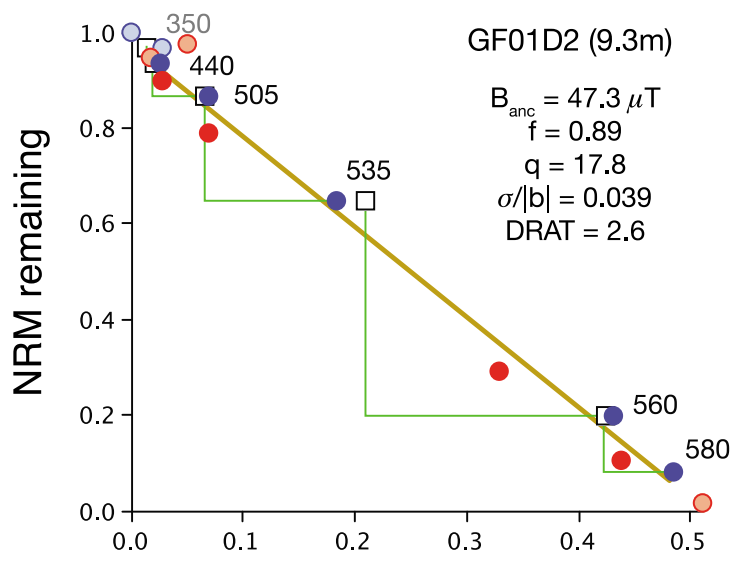

C

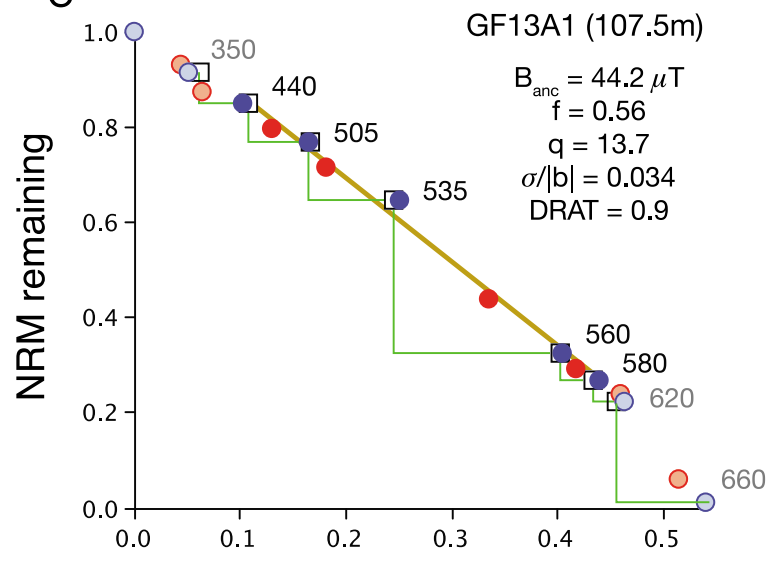

E

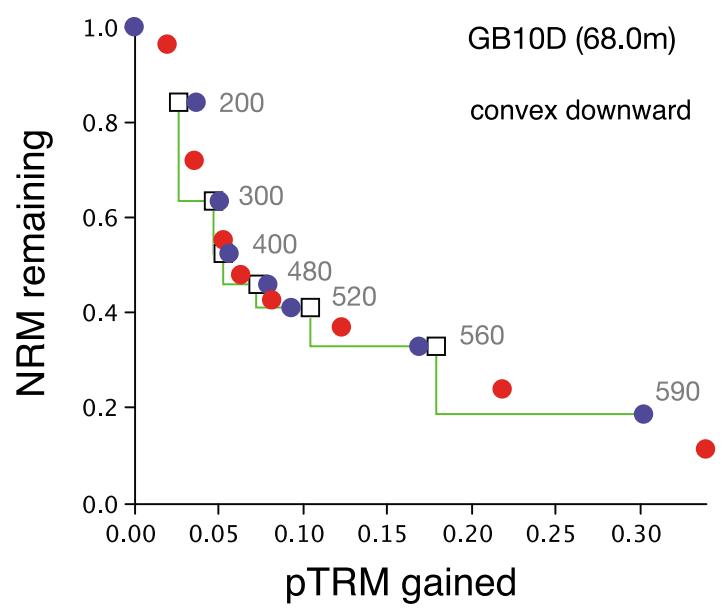

B

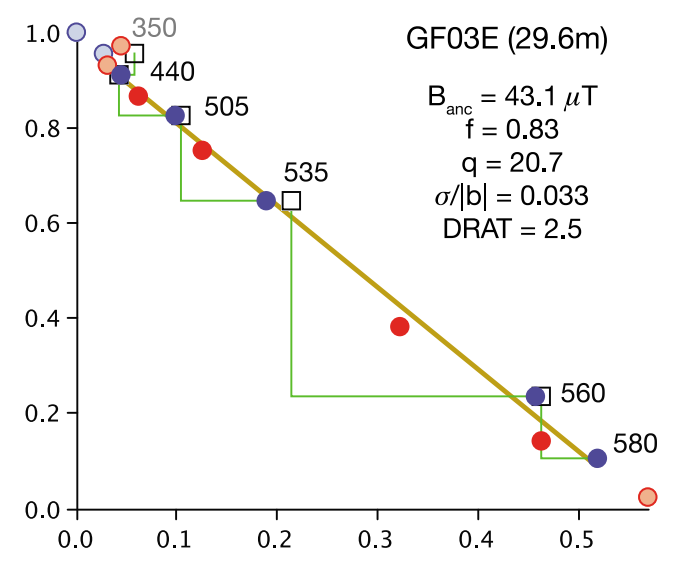

D

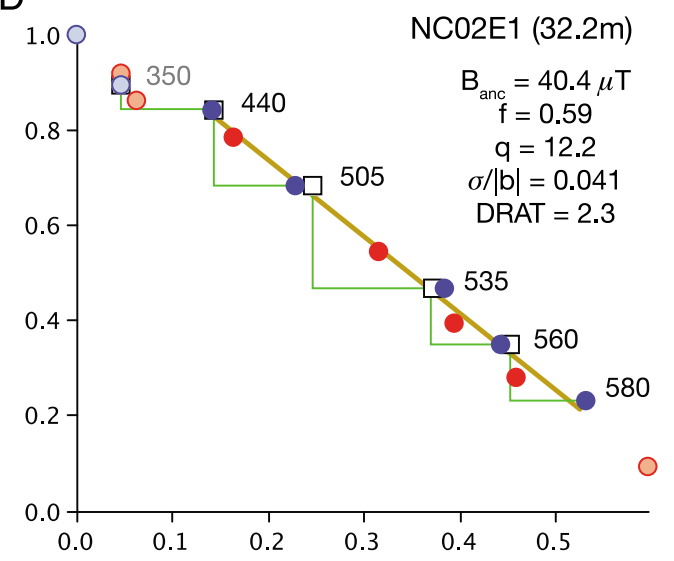

$\mathrm{F}$

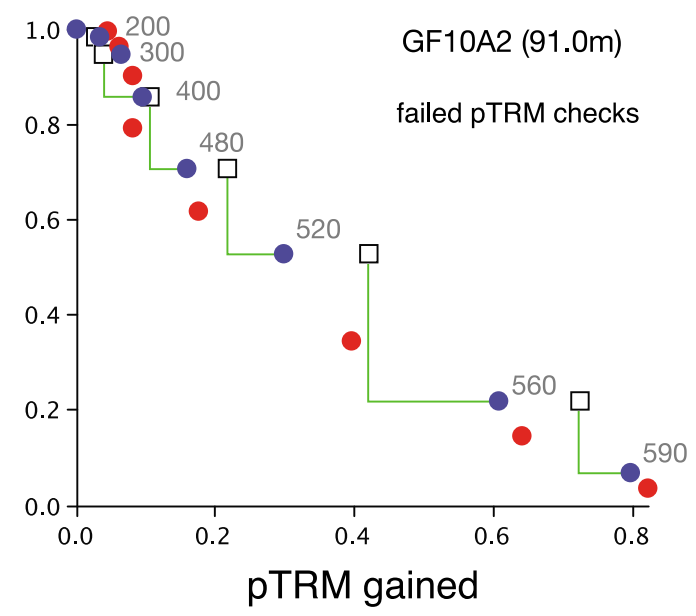

Figure 6. Representative Arai plots illustrating (a-d) successful and (e and f) failed paleointensity determinations for samples from Bishop Tuff. Zero-field followed by in-field cooling (ZI) steps are shown in blue, and in-field followed by zero-field (IZ) steps are shown in red. The pTRM checks are shown with boxes and green lines. Temperature values for IZ steps are gray where not used for slope calculation. See section 5 for selection criteria.

poorly defined slopes calculated from the highesttemperature interval $\left(580^{\circ} \mathrm{C}-660^{\circ} \mathrm{C}\right)$. More than half of the paleointensity estimates with DRAT $>5$ have ancient field values below $30 \mu \mathrm{T}$, indicating that the tail of lower-intensity estimates in this distribution in Figure 7c is associated with poor pTRM checks. Although arbitrary, these cutoff values result in an internally consistent data set 

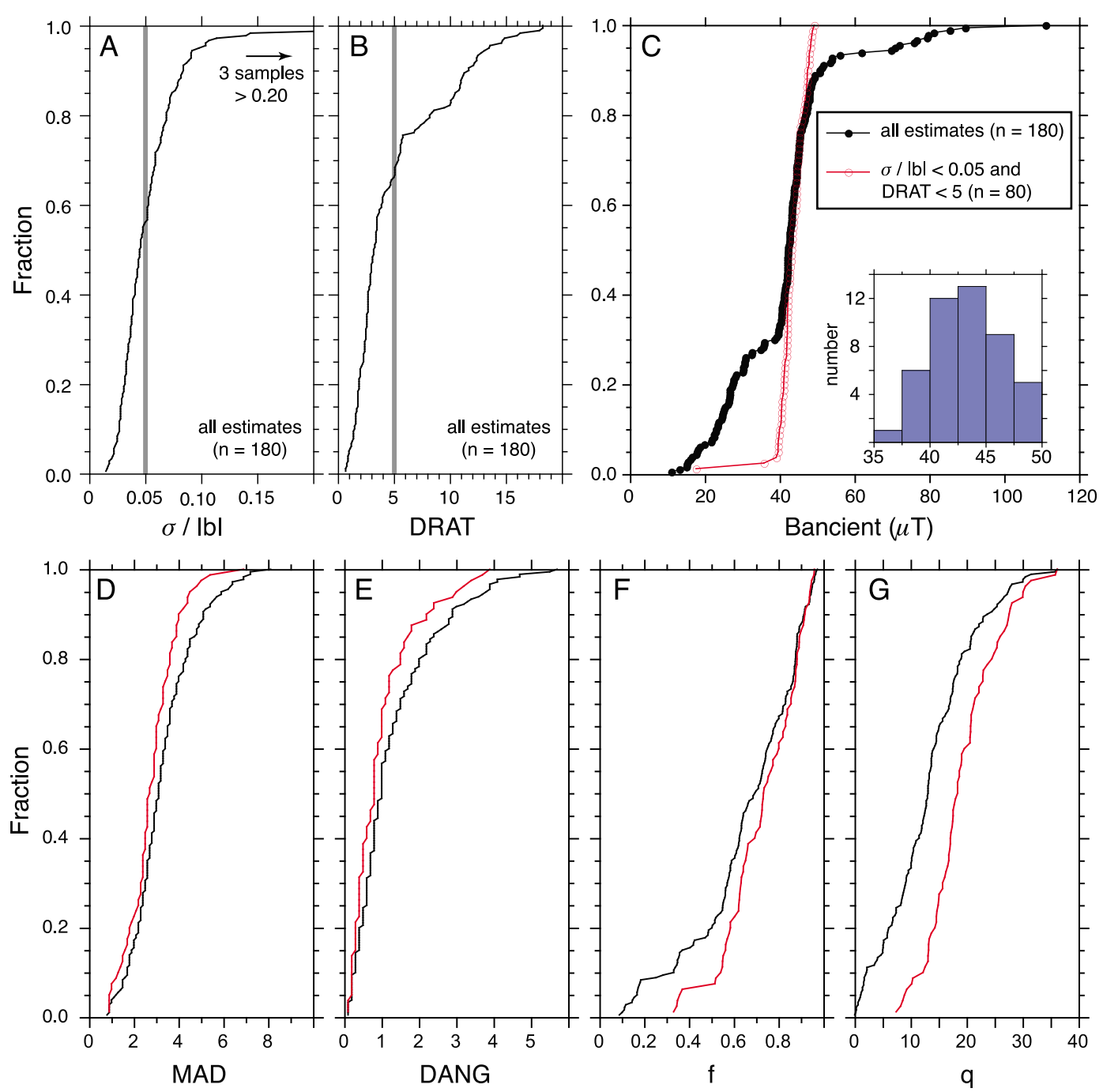

Figure 7. Cumulative distribution functions for paleointensity estimates and reliability selection criteria. Distribution of (a) normalized error (s/lbl) and (b) pTRM check agreement (DRAT) for all paleofield estimates. Note that multiple estimates over different temperature ranges were made for each specimen (see section 5 for details). Vertical bars indicate the cutoff values used. (c) Distribution of paleofield estimates for complete data set (black) and filtered data set (red). Histogram inset shows distribution for the lower-temperature range ("magnetite") estimates for the 46 specimens that have $\sigma /|\mathrm{bl}|<0.05$ and DRAT values $<5$. (d-g) The corresponding distributions for additional reliability criteria for the complete (black) and filtered (red) data sets.

and, with a single exception (with paleofield of $17 \mu \mathrm{T}$ in Figure 7c), exclude all specimens with curved Arai plots (e.g., Figures 6e and 6f).

[32] The result of these two selection criteria on other reliability parameters is shown in Figures $7 \mathrm{~d}-$ $7 \mathrm{~g}$. The resulting data are characterized by zero-field remanence data that define a low scatter component (MAD angles for $90 \%$ are $<4^{\circ}$ [Kirschvink, 1980]) that trends to the origin (DANG, the angle between the principal component anchored to and free from the origin, is $<4^{\circ}$ ). The average fraction of the remanence (f) and the mean quality factor (q) [Coe et al., 1978] are 0.73 and 19 , respectively.
[33] Comparison of paleofield estimates that pass these selection criteria (80 estimates from 46 specimens) allows examination of whether low and high unblocking temperature phases yield consistent values. Paleofield estimates from the lowesttemperature interval $\left(440^{\circ} \mathrm{C}-580^{\circ} \mathrm{C}\right)$ are typically within a few $\mu \mathrm{T}$ of those calculated over the expanded temperature range of $440^{\circ} \mathrm{C}-600^{\circ} \mathrm{C}$ (regression yields a correlation coefficient of $\mathrm{R}=0.91$ ). This suggests that nonstoichiometric magnetite, presumably responsible for unblocking over $580^{\circ} \mathrm{C}-600^{\circ} \mathrm{C}$, may be formed early and carry a thermoremanence (as inferred below for the "magnetite" component unblocked by $580^{\circ} \mathrm{C}$ ) or possibly a thermochemical 
A
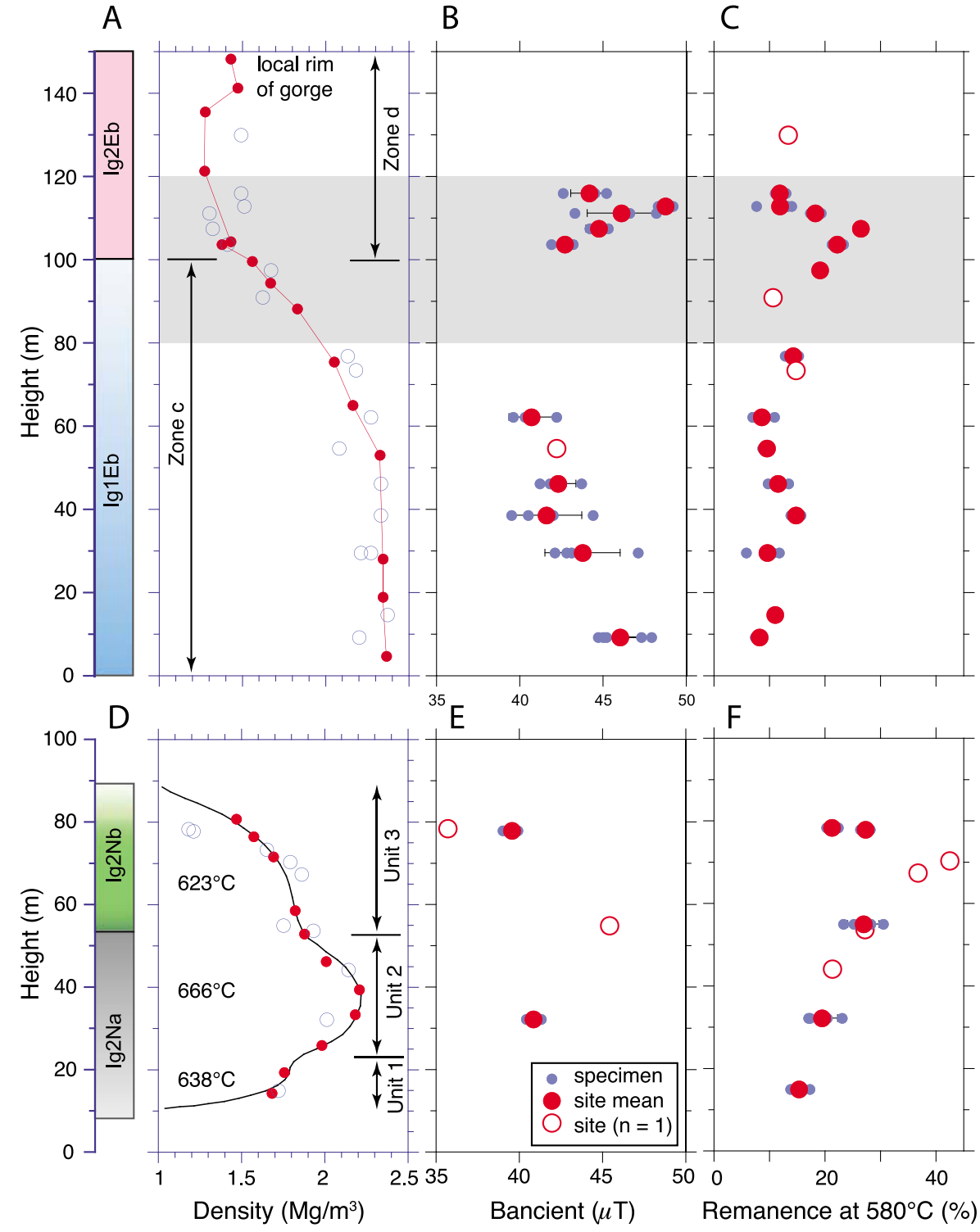

Figure 8. Stratigraphic variation for the $(\mathrm{a}-\mathrm{c}) \mathrm{GF}$ and $(\mathrm{d}-\mathrm{f}) \mathrm{NC}$ sections of successful paleointensity determinations (Figures $8 \mathrm{~b}$ and $8 \mathrm{e}$ ) and remanence remaining at $580^{\circ} \mathrm{C}$ (as percentage of initial remanence (Figures $8 \mathrm{c}$ and $8 \mathrm{f}$ )). No successful paleointensities were obtained from the GB section. Lithology and density plots as in Figure 2. Horizontal gray bar in GF section shows approximate location of oxygen isotopic depletion from Holt and Taylor [1998].

remanence. Only five specimens have paleointensity estimates from the broadest $\left(440^{\circ} \mathrm{C}-660^{\circ} \mathrm{C}\right)$ and low-temperature $\left(440^{\circ} \mathrm{C}-580^{\circ} \mathrm{C}\right)$ intervals that pass the selection criteria. Three of these pairs differ by less than $0.5 \mu \mathrm{T}$ and for the remaining two the broader temperature range yields a paleofield estimate higher by approximately $2 \mu \mathrm{T}$.

[34] The highest-temperature paleofield estimate $\left(580^{\circ} \mathrm{C}-660^{\circ} \mathrm{C}\right)$ has a distinctly steeper slope (e.g., Figure 6c) though none of these estimates passes the selection criteria. We suggest that the remanence carried by the high-temperature minerals is a thermochemical remanence (TCRM), acquired as the minerals either precipitated/grew or underwent thermochemical alteration (mineralogical transformation?) during cooling at or below their Curie temperature. Such steeper slopes on Arai plots have been documented for TCRM associated with decomposition of Ti-rich titanomagnetite [Draeger et al., 2006] and may also reflect the oxidation of magnetite to maghemite [Fabian, 2009].

[35] For the 46 specimens having paleointensity estimates from one or more temperature intervals that pass our selection criteria, we selected the lowest-temperature interval as most representative (the upper bound coincides with the Curie temper- 
Table 1. Average Paleointensity Values for Block Samples From the Bishop Tuff

\begin{tabular}{lcccc}
\hline \multicolumn{1}{c}{ Block } & Height $(\mathrm{m})$ & $\mathrm{N}^{\mathrm{a}}$ & $\mathrm{B}(\mu \mathrm{T})$ & $\mathrm{SD}$ \\
\hline GF01 & 9.3 & $5(5)$ & 46.0 & 1.5 \\
GF03 & 29.6 & $4(4)$ & 43.8 & 2.3 \\
GF04 & 38.6 & $4(4)$ & 41.6 & 2.1 \\
GF05 & 46.2 & $4(4)$ & 42.3 & 1.1 \\
GF06 & 54.7 & $1(3)$ & 42.2 & \\
GF07 & 62.2 & $3(4)$ & 40.7 & 1.3 \\
Ig1Eb (zone c) & & 6 & 42.8 & 1.9 \\
& & & & \\
GF12 & 103.7 & $3(4)$ & 42.7 & 0.7 \\
GF13 & 107.5 & $2(2)$ & 44.8 & 0.8 \\
GF14 & 111.2 & $4(4)$ & 46.1 & 2.0 \\
GF15 & 112.9 & $3(4)$ & 48.7 & 0.5 \\
GF16 & 116.0 & $4(4)$ & 44.2 & 1.1 \\
Ig2Eb (zone d) & & 5 & 45.3 & 2.3 \\
& & & & \\
NC02 & 32.2 & $3(4)$ & 40.8 & 0.5 \\
Ig2Na (unit 2) & & 1 & 40.8 & \\
& & & & \\
NC05 & 55.0 & $1(5)$ & 45.4 & \\
NC09 & 77.9 & $4(5)$ & 39.6 & 0.4 \\
NC10 & 78.4 & $1(5)$ & 35.7 & \\
Ig2Nb (unit 3) & & 3 & 40.2 & 4.9 \\
Overall mean & & & & \\
\hline
\end{tabular}

${ }^{a}$ Number of successful results with number of specimens attempted in parentheses.

ature of the dominant phase identified in thermomagnetic curves). Eight of these estimates were based on the extended temperature interval $\left(440^{\circ} \mathrm{C}-\right.$ $600^{\circ} \mathrm{C}$ ), with the remaining estimates based on the low-temperature interval $\left(440^{\circ} \mathrm{C}-580^{\circ} \mathrm{C}\right.$ or $440^{\circ} \mathrm{C}-$ $570^{\circ} \mathrm{C}$ ). Successful paleointensity results were obtained from 11 blocks from the GF section and 4 from the NC section (Figure 8). Twelve of these blocks had multiple paleointensity estimates and the within-site standard deviation ranges from 0.4 to $2.3 \mu \mathrm{T}$ (mean $1.2 \mu \mathrm{T}$ ). The overall mean of the 15 sites is $43.0 \pm 3.2 \mu \mathrm{T}$ (Table 1 ) is equivalent to a VADM of $7.8 \times 10^{22} \mathrm{Am}^{2}$. This value compares favorably with the mean VADM $(7.48 \pm$ $1.26 \times 10^{22} \mathrm{Am}^{2}, \mathrm{n}=6$ ) of the small number of paleointensity estimates in the $0.75-0.77 \mathrm{Ma}$ interval in the PINT2006 database [Tauxe, 2006].

\section{Discussion}

[36] The magnetization in the Bishop Tuff may include both thermal and chemical remanence as a result of the complex magnetic mineralogy and heterogeneity in the thermal and alteration history. Thermomagnetic curves suggest that low-Ti titanomagnetite $\left(\mathrm{T}_{\mathrm{c}}=560^{\circ} \mathrm{C}-580^{\circ} \mathrm{C}\right)$ is the dominant phase in the GF and $\mathrm{NC}$ sections, with a minor contribution from a higher $\mathrm{T}_{\mathrm{c}}$ phase. The latter phase is more prominent in the remanence, as evidenced by significant unblocking above $580^{\circ} \mathrm{C}$ (Figure 8) in most samples. Hysteresis data provide evidence for a high-coercivity phase in some poorly welded sections (upper GF and NC sections) and the high unblocking temperatures in these specimens may reflect the presence of (titano)hematite. Specimens from more densely welded sections have hysteresis loops that saturate by $1 \mathrm{~T}$, suggesting that the high unblocking temperature phase elsewhere likely represents thermally stable maghemite [Palmer et al., 1996; Özdemir, 1990]. In this section we briefly review the possible origins of the magnetic phases in the Bishop Tuff and the implications for the type of remanence and the timing of remanence acquisition.

[37] Titanomagnetite is common as a crystal phase in the Bishop Tuff but is unlikely to contribute significantly to the remanence of samples that yielded successful paleointensity estimates. Titanomagnetite constitutes only $0.05 \%-0.5 \%$ of the total phenocryst assemblage (total phenocrysts range from $<1 \%$ to $24 \%$ ) and therefore less than $0.1 \%$ by volume of tuff samples [Hildreth and Wilson, 2007]. Moreover, the titanomagnetite composition is relatively uniform, with ulvöspinel contents of 25-28 mol \% [Hildreth, 1979], and these grains should have Curie temperatures $<450^{\circ} \mathrm{C}$ [e.g., Dunlop and Özdemir, 1997]. The only specimens with substantial unblocking of NRM below $450^{\circ} \mathrm{C}$ are also generally associated with convex downward Arai plots (Figure 6e), which would be consistent with the presence of multidomain-sized crystals. In most of the Bishop Tuff, however, titanomagnetite crystals (at least if unaltered or without oxyexsolution) appear to be an insignificant contributor to the remanence. We are not aware of any studies documenting oxyexsolution in titanomagnetite crystals in the Bishop Tuff and, indeed, homogeneous FeTi oxide pairs form the basis for magmatic temperature estimates of the tuff [e.g., Hildreth, 1979; Hildreth and Wilson, 2007]. If oxyexsolution is rare, then the titanomagnetite crystals would be unlikely as the source of the dominant $560^{\circ} \mathrm{C}-580^{\circ} \mathrm{C} \mathrm{T}_{\mathrm{c}}$ in these samples.

[38] An alternative, and perhaps more plausible, source for the remanence is the presence of finergrained magnetite that is produced after emplacement. Palmer et al. [1996] noted the presence of oxide microcrystals that they interpreted as similar to those imaged in other tuffs [e.g., Schlinger et al., 1991]. Although hysteresis data fall within the PSD range, the contribution of SP grains inferred from 
the shapes of some hysteresis loops suggests that a range of grain sizes, including fine SD or SD-like particles, may be present in many Bishop Tuff samples. If sufficiently abundant, the glass-hosted microcrystals (presumably of Ti-poor titanomagnetite) might account for the dominant $560^{\circ} \mathrm{C}-$ $580^{\circ} \mathrm{C}$ Curie temperature and similar Curie temperatures have been documented for vitrophyres of ash flow tuffs [Geissman et al., 1983]. We cannot, however, exclude the possibility that similar $\mathrm{Ti}^{-}$ poor titanomagnetite might also be produced by oxyexsolution.

[39] The coincidence of oxygen isotopic [Holt and Taylor, 1998] and magnetic data from our GF section allows some inferences on the magnetic effects of postemplacement alteration to be made. Circulation of meteoric hydrothermal fluids in this section was restricted to the less densely welded upper part of the tuff, with the densely welded tuff forming a permeability boundary and presumably also providing the source of heat. The $\sim 40 \mathrm{~m}$ interval of oxygen isotopic depletion, indicative of vapor phase alteration and associated with pervasive devitrification, documented by Holt and Taylor [1998] apparently straddles the boundary between stratigraphic units $\mathrm{Ig} 1 \mathrm{~Eb}$ and $\mathrm{Ig} 2 \mathrm{~Eb}$. We observe a pronounced reduction of remanence and susceptibility (Figure 2) throughout the upper stratigraphic unit (Ig2Eb). The order of magnitude reduction in $\mathrm{Ig} 2 \mathrm{~Eb}$ relative to the underlying unit cannot be explained by compaction alone (density differences imply at most a factor of 2 enhancement). Rather, decreased magnetization intensity and susceptibility are more likely related to extensive vapor phase alteration. Palmer et al. [1996] attributed a similar reduction in the upper tuff (a few $\mathrm{km}$ to the south of our GF section) to alteration to hematite and rutile. This is compatible with our observation of a high-coercivity phase in the upper portion of the GF section that we attribute to (titano)hematite.

[40] It is less clear whether oxidation to maghemite is related to meteoric hydrothermal alteration. The interval of depleted oxygen isotopes in the GF section appears to coincide with slightly higher fractions of maghemite, as inferred from the amount of remanence remaining at $580^{\circ} \mathrm{C}$ (Figure 8), suggesting that vapor phase alteration might be associated with oxidation of magnetite to maghemite. However, both remanence data and thermomagnetic curves (Figures 4 and 5) suggest that maghemite is also present in the densely welded lower portions of section GF that have experienced little if any exchange with meteoric hydrothermal fluids [Holt and Taylor, 1998]. It seems possible that maghemite formation in the low-permeability portion of the tuff may have occurred early, and possibly at high temperatures, during the initial stages of cooling.

[41] Emplacement temperatures for the NC section and the lower, densely welded unit in the GF section were likely well above $600^{\circ} \mathrm{C}$ and perhaps as high as $660^{\circ} \mathrm{C}$. We suggest that paleointensity estimates from the lowest-temperature interval (typically $440^{\circ} \mathrm{C}-580^{\circ} \mathrm{C}$ ) reflect the remanence of finegrained magnetite that most probably carries a TRM. This interpretation is based on the assumption that this magnetite formed at high temperatures (above $580^{\circ} \mathrm{C}$ ) shortly after emplacement, when temperatures are highest and the kinetics of magnetite nucleation and growth in glass shards would presumably be most favorable. Nonetheless, it is possible that some or all of the magnetite was produced at temperatures below the Curie point $\left(580^{\circ} \mathrm{C}\right)$ and oxidation to maghemite may also have occurred at temperatures below the $\mathrm{T}_{\mathrm{c}}$ for this phase $\left(645^{\circ} \mathrm{C}\left[\ddot{O}_{z}\right.\right.$ demir, 1990]). In these cases, the remanence may in part be a thermochemical remanence (TCRM).

[42] The slopes on an Arai plot for a TRM and TCRM are not generally expected to be the same [e.g., Fabian, 2009]. One might therefore expect that if magnetite were produced at a temperature below the Curie point that a break in slope might be observed on the Arai plots at some lower temperature. The linearity of Arai plots over $440^{\circ} \mathrm{C}-$ $580^{\circ} \mathrm{C}$ and the consistency of the slopes obtained over this temperature interval may therefore provide some support for the inference that magnetite was produced above its Curie temperature and that the remanence carried is a TRM. We do observe a break in slope at $\sim 580^{\circ} \mathrm{C}$ on some Arai plots (e.g., Figure 6c), this higher-temperature slope may reflect a TCRM. This TCRM may be carried by (titano)hematite in the less densely welded upper part of the tuff, and by maghemite in the more densely welded part of the tuff that experienced little exchange with meteoric hydrothermal fluids.

\section{Conclusions}

[43] With the exception of lavas or archeological materials from historic times, for which the geomagnetic field intensity is independently known, the validity of all other absolute paleointensity estimates must be established more indirectly. One common criterion for assessing reliability is internal 
consistency among specimens with linear Arai plots and otherwise positive tests for technical reliability. Samples from the Bishop Tuff have low within-site scatter and the standard deviation of results from 15 sites $(7.4 \%=$ standard deviation/ mean paleointensity) is comparable to or smaller than that obtained from similar studies of other geological materials (e.g., mafic lavas). The low scatter may, in part, be due to our cutoff values for DRAT and $\sigma / \mathrm{lb}$, which were designed to filter out poor quality results on the tails of the paleointensity distribution. We note that for 7 of the successful sites no specimens were rejected and for 4 additional sites only a single specimen (with a paleofield within a few $\mu \mathrm{T}$ of the mean) failed our selection criteria. Thus, the internal consistency of the paleointensity results does not appear to be primarily a result of our selection criteria.

[44] The consistency of paleointensity values from specimens with a range of thermal and alteration histories also suggests that the absolute intensity estimates accurately reflect the ancient field intensity. For example, densely welded specimens from the lower part of the GF section, which experienced little alteration, yield paleointensities similar to those from the more pervasively altered upper part of this section (Figure 8 and Table 1). Similar, though more scattered, paleofield values were also obtained from two cooling units in the NC section, including from the top of this section where the magnetic mineralogy includes a significant contribution from hematite. We emphasize that the similar paleofield values were obtained from the lower-temperature, "magnetite" component in all cases. This suggests that sufficient fine-grained magnetite may be present and may preserve a consistent TRM, even where the subsequent alteration history is complex.

[45] The technical quality and internal consistency of the paleointensity data from the Bishop Tuff do not guarantee that the resulting paleointensities accurately reflect the ancient field intensity. Nonetheless, the paleointensity estimates from the Bishop Tuff, together with direct evidence for ultrafine magnetic particles in similar material, suggests that carefully selected samples from ignimbrites may constitute a viable material for reliable paleointensity determinations.

\section{Acknowledgments}

[46] This research was supported by NSF grant EAR0521374 to J. S. Gee and Y. Yu. We thank J. Geissman, S. Bogue,
M. Jackson, and J. Tarduno for their helpful comments that improved the manuscript. We thank Elise Sbarbori for help with sampling. The field work was facilitated by use of the University of California White Mountain Research Station in Bishop, California. This is Institute for Rock Magnetism contribution 0906.

\section{References}

Ade-Hall, J. M., H. C. Palmer, and T. P. Hubbard (1971), The magnetic and opaque petrological response of basalts to regional hydrothermal alteration, Geophys. J. R. Astron. Soc., 24, 137-174.

Anderson, A. T., A. M. Davis, and F. Lu (2000), Evolution of Bishop Tuff rhyolitic magma based on melt and magnetite inclusions and zoned phenocrysts, J. Petrol., 41, 449-473, doi:10.1093/petrology/41.3.449.

Banks, N. G., and R. P. Hoblitt (1981), Summary of temperature studies of 1980 deposits, in The 1980 Eruptions of Mount St. Helens, edited by P. W. Lipman and D. R. Mullineaux, U.S. Geol. Surv. Prof. Pap., 1250, 295-313.

Banks, N. G., and R. P. Hoblitt (1996), Direct temperature measurements of deposits, Mount St. Helens, Washington, 1980-1981, U.S. Geol. Surv. Prof. Pap., 1387, 76 pp.

Bardot, L., and E. McClelland (2000), The reliability of emplacement temperature estimates using palaeomagnetic methods: A case study from Santorini, Greece, Geophys. J. Int., 143, 39-51, doi:10.1046/j.1365-246x.2000.00186.x.

Biggin, T., and D. N. Thomas (2003), Analysis of long-term variations in the geomagnetic poloidal field intensity and evaluation of their relationship with global geodynamics, Geophys. J. Int., 152, 392-415, doi:10.1046/j.1365246X.2003.01849.x.

Bowles, J., J. S. Gee, D. V. Kent, M. R. Perfit, S. A. Soule, and D. J. Fornari (2006), Paleointensity applications to timing and extent of eruptive activity, $9^{\circ}-10^{\circ} \mathrm{N}$ East Pacific Rise, Geochem. Geophys. Geosyst., 7, Q06006, doi:10.1029/ 2005GC001141.

Bowles, J. A., J. S. Gee, K. Burgess, and R. F. Cooper (2008), A controlled evaluation of magnetite formation in synthetic submarine basaltic glass: Implications for paleointensity studies, Eos Trans. AGU, 89(53), Fall Meet. Suppl., Abstract GP51B-0768.

Carlut, J., and D. V. Kent (2000), Paleointensity record in zeroage submarine basalt glass: Testing a new dating technique for recent MORBs, Earth Planet. Sci. Lett., 183, 389-401, doi:10.1016/S0012-821X(00)00291-0.

Coe, R. S., C. S. Grommé, and E. A. Mankinen (1978), Geomagnetic paleointensities from radiocarbon-dated lava flows on Hawaii and the question of the Pacific nondipole low, J. Geophys. Res., 83, 1740-1756, doi:10.1029/ JB083iB04p01740.

Deubener, J., R. Müller, H. Behrens, and G. Heide (2003), Water and the glass transition temperature of silicate melts, J. Non Cryst. Solids, 330, 268-273, doi:10.1016/S00223093(03)00472-1.

Draeger, U., M. Prévot, T. Poidras, and J. Riisager (2006), Single-domain chemical, thermochemical and thermal remanences in a basaltic rock, Geophys. J. Int., 166, 12-32, doi:10.1111/j.1365-246X.2006.02862.x.

Dunbar, N. W., and R. L. Hervig (1992), Petrogenesis and volatile stratigraphy of the Bishop Tuff: Evidence from melt inclusion analysis, J. Geophys. Res., 97, 15,12915,150, doi:10.1029/92JB00764. 
Dunlop, D. J. (2002), Theory and application of the Day plot $\left(M_{r s} / M_{s}\right.$ versus $\left.H_{c r} / H_{c}\right): 1$. Theoretical curves and tests using titanomagnetite data, J. Geophys. Res., 107(B3), 2056, doi:10.1029/2001JB000486.

Dunlop, D. J., and Ö. Özdemir (1997), Rock Magnetism, Fundamentals and Frontiers, 573 pp., Cambridge Univ. Press, Cambridge, U. K.

Fabian, K. (2009), Thermochemical remanence acquisition in single-domain particle ensembles: A case for possible overestimation of the geomagnetic paleointensity, Geochem. Geophys. Geosyst., 10, Q06Z03, doi:10.1029/2009GC002420.

Geissman, J. W., N. G. Newberry, and D. R. Peacor (1983), Discrete single-domain and pseudo-single-domain titanomagnetite particle in silicic glass of an ash-flow tuff, Can. J. Earth Sci., 20, 334-338.

Giordano, D., A. R. L. Nichols, and D. B. Dingwell (2005), Glass transition temperatures of natural hydrous melts: A relationship with shear viscosity and implications for the welding process, J. Volcanol. Geotherm. Res., 142, 105-118.

Grommé, C. S., T. L. Wright, and D. L. Peck (1969), Magnetic properties and oxidation of iron-titanium oxide minerals in Alae and Makopuhi lava lakes, Hawaii, J. Geophys. Res., 74, 5277-5294, doi:10.1029/JB074i022p05277.

Grunder, A. L., D. Laporte, and T. H. Druitt (2005), Experimental and textural investigation of welding: Effects of compaction, sintering, and vapor-phase crystallization in the rhyolitic Rattlesnake Tuff, J. Volcanol. Geotherm. Res., 142, 89-104, doi:10.1016/j.jvolgeores.2004.10.018.

Hildreth, W. (1979), The Bishop Tuff: Evidence for the origin of compositional zonation in silicic magma chambers, Spec. Pap. Geol. Soc. Am., 180, 43-75.

Hildreth, W., and C. J. N. Wilson (2007), Compositional zoning of the Bishop Tuff, J. Petrol., 48, 951-999, doi:10.1093/ petrology/egm007.

Hoblitt, R. P., and K. S. Kellog (1979), Emplacement temperatures of unsorted and unstratified deposits of volcanic rock debris as determined by paleomagnetic techniques, Geol. Soc. Am. Bull., 90, 633-642, doi:10.1130/0016-7606(1979) $90<633$ :ETOUAU $>2.0 . \mathrm{CO} ; 2$.

Hogeweg, N., T. E. C. Keith, E. M. Colvard, and S. E. Ingebritsen (2005), Ongoing hydrothermal heat loss from the 1912 ash-flow sheet, Valley of Ten Thousand Smokes, Alaska, J. Volcanol. Geotherm. Res., 143, 279-291, doi:10.1016/ j.jvolgeores.2004.12.003.

Holt, E. W., and H. P. Taylor (1998), ${ }^{18} \mathrm{O} /{ }^{16} \mathrm{O}$ mapping and hydrogeology of a short-lived $(\sim 10$ years $)$ fumarolic $\left(>500^{\circ} \mathrm{C}\right)$ meteoric-hydrothermal event in the upper part of the $0.76 \mathrm{Ma}$ Bishop Tuff outflow sheet, California, J. Volcanol. Geotherm. Res., 83, 115-139, doi:10.1016/S0377-0273(98) 00014-6.

Holt, E. W., and H. P. Taylor Jr. (2001), ${ }^{18} \mathrm{O} /{ }^{16} \mathrm{O}$ studies of fossil fissure fumaroles from the Valley of Ten Thousand Smokes, Alaska, Bull. Volcanol., 63, 151-163, doi:10.1007/ s004450100131.

Keating, G. N. (2005), The role of water in cooling ignimbrites, J. Volcanol. Geotherm. Res., 142, 145-171, doi:10.1016/j.jvolgeores.2004.10.019.

Keith, T. E. C. (1991), Fossil and active fumaroles in the 1912 eruptive deposits, Valley of Ten Thousand Smokes, Alaska, J. Volcanol. Geotherm. Res., 45, 227-254, doi:10.1016/ 0377-0273(91)90061-4.

Keith, T. E. C., and L. J. P. Muffler (1978), Minerals produced during cooling and hydrothermal alteration of ash flow tuff from Yellowstone drill hole Y-5, J. Volcanol. Geotherm. Res., 3, 373-402, doi:10.1016/0377-0273(78)90044-6.
Kent, D. V., D. Ninkovich, T. Pescatore, and R. S. J. Sparks (1981), Paleomagnetic determination of emplacement temperature of the Vesuvius 79 AD pyroclastic deposit, Nature, 290, 393-396, doi:10.1038/290393a0.

Kirschvink, J. L. (1980), The least squares line and plane and the analysis of paleomagnetic data, Geophys. J. R. Astron. Soc., 62, 699-718.

Lipman, P. W., D. R. Norton, J. E. Taggart Jr., E. L. Brandt, and E. E. Engleman (1981), Compositional variations in 1980 magmatic deposits, U.S. Geol. Surv. Prof. Pap., 1250, 631-640.

McClelland, E. A., and T. H. Druitt (1989), Paleomagnetic estimates of emplacement temperatures of pyroclastic deposits on Santorini, Greece, Bull. Volcanol., 51, 16-27, doi:10.1007/BF01086758.

McClelland, E., C. J. N. Wilson, and L. Bardot (2004), Palaeotemperature determinations for the 1.8-ka Taupo ignimbrite, New Zealand, and implications for the emplacement history of a high-velocity pyroclastic flow, Bull. Volcanol., 66, 492513, doi:10.1007/s00445-003-0335-5.

McIntosh, W. C., J. F. Sutter, C. E. Chapin, and L. L. Kedzie (1990), High precision ${ }^{40} \mathrm{Ar} /{ }^{39} \mathrm{Ar}$ sanidine geochronology of ignimbrites in the Mogollon-Datil volcanic field, southwestern New Mexico, Bull. Volcanol., 52, 584-601, doi:10.1007/ BF00301210.

Mejia, V., N. D. Opdyke, and M. R. Perfit (1996), Paleomagnetic field intensity recorded in submarine basaltic glass from the East Pacific Rise, the last $69 \mathrm{ka}$, Geophys. Res. Lett., 23, 475-478, doi:10.1029/96GL00018.

Moskowitz, B. M. (1981), Methods for estimating Curie temperatures of titanomaghemites from experimental $\mathrm{J}_{\mathrm{s}}-\mathrm{T}$ data, Earth Planet. Sci. Lett., 53, 84-88, doi:10.1016/0012-821X (81)90028-5.

Nagata, T., Y. Arai, and K. Momose (1963), Secular variation of the geomagnetic field total force during the last 5000 years, J. Geophys. Res., 68, 5277-5281.

Özdemir, Ö. (1990), High-temperature hysteresis and thermoremanence of single-domain maghemite, Phys. Earth Planet. Inter., 65, 125-136, doi:10.1016/0031-9201(90)90081-8.

Palmer, H. C., W. D. MacDonald, C. S. Grommé, and B. B. Ellwood (1996), Magnetic properties and emplacement of the Bishop tuff, California, Bull. Volcanol., 58, 101-116, doi:10.1007/s004450050129.

Pick, T., and L. Tauxe (1993), Geomagnetic paleointensities during the Cretaceous normal superchron measured using submarine basaltic glass, Nature, 366, 238-242, doi: $10.1038 / 366238 \mathrm{a} 0$.

Pick, T., and L. Tauxe (1994), Characteristics of magnetite in submarine basaltic glass, Geophys. J. Int., 119, 116-128, doi:10.1111/j.1365-246X.1994.tb00917.x.

Reynolds, R. L. (1977), Paleomagnetism of welded tuffs of the tuffs of the Yellowstone group, J. Geophys. Res., 82, 36773693, doi:10.1029/JB082i026p03677.

Riehle, J. R. (1973), Calculated compaction profiles of ryolitic ash flow tuffs, Geol. Soc. Am. Bull., 84, 2193-2216, doi:10.1130/0016-7606(1973)84<2193:CCPORA $>2.0$. $\mathrm{CO} ; 2$.

Riehle, J. R., T. F. Miller, and R. A. Bailey (1995), Cooling degassing and compaction of rhyolitic ash flow tuffs: A computational model, Bull. Volcanol., 57, 319-336.

Rosenbaum, J. G. (1993), Magnetic grain-size variations through an ash flow sheet: Influence on magnetic properties and implications for cooling history, J. Geophys. Res., 98, 11,715-11,727, doi:10.1029/93JB00355. 
Russell, J. K., and S. L. Quane (2005), Rheology of welding: Inversion of field constraints, J. Volcanol. Geotherm. Res., 142, 173-191, doi:10.1016/j.jvolgeores.2004.10.017.

Sarna-Wojcicki, A. M., M. S. Pringle, and J. Wijbrans (2000), New ${ }^{40} \mathrm{Ar} /{ }^{39} \mathrm{Ar}$ age of the Bishop Tuff from multiple sites and sediment rate calibration for the Matuyama-Brunhes boundary, J. Geophys. Res., 105, 21,431-21,444.

Schlinger, C. M., J. G. Rosenbaum, and D. R. Veblen (1988a), Fe-oxide microcrystals in welded tuff from southern Nevada: Origin of remanence carriers by precipitation in volcanic glass, Geology, 16, 556-559, doi:10.1130/0091-7613(1988) $016<0556$ :FOMIWT $>2.3 . \mathrm{CO} ; 2$.

Schlinger, C. M., D. Griscom, G. Papaefthymiou, and D. R. Veblen (1988b), The nature of magnetic single-domains in volcanic glasses of the KBS tuff, J. Geophys. Res., 93, 9137-9156, doi:10.1029/JB093iB08p09137.

Schlinger, C. M., D. R. Veblen, and J. G. Rosenbaum (1991), Magnetism and magnetic mineralogy of ash flow tuffs from Yucca Mountain, Nevada, J. Geophys. Res., 96, 6035-6052, doi:10.1029/90JB02653.

Schnepp, E. (1995), Palaeointensity study of Quaternary East Eifel phonolitic rocks (Germany), Geophys. J. Int., 121, 627-633, doi:10.1111/j.1365-246X.1995.tb05737.x.

Selkin, P., and L. Tauxe (2000), Long-term variations in paleointensity, Philos. Trans. R. Soc. London, Ser. A, 358, 1065-1088, doi:10.1098/rsta.2000.0574.

Sheridan, M. F. (1970), Fumarolic mounds and ridges of the Bishop Tuff, California, Geol. Soc. Am. Bull., 81, 851868, doi:10.1130/0016-7606(1970)81[851:FMAROT]2.0. $\mathrm{CO} ; 2$.

Sheridan, M. F., and D. M. Ragan (1976), Compaction of ashflow tuffs, in Developments in Sedimentology 2, pp. 677717, Elsevier, New York.

Sheridan, M. F., and Y. Wang (2005), Cooling and welding history of the Bishop Tuff in Adobe Valley and Chidago Canyon, California, J. Volcanol. Geotherm. Res., 142, 119-144, doi:10.1016/j.jvolgeores.2004.10.016.

Tanaka, H., A. Otsuka, T. Tachibana, and M. Kono (1994), Paleointensities for 10-22 ka from volcanic rocks in Japan and New Zealand, Earth Planet. Sci. Lett., 122, 29-42, doi:10.1016/0012-821X(94)90049-3.

Tanaka, H., N. Komuro, and G. M. Turner (2009), Palaeosecular variation for $0.1-21 \mathrm{Ka}$ from the Okataina Volcanic Centre, New Zealand, Earth Planets Space, 61, 213-225.
Tauxe, L. (2006), Long-term trends in paleointensity: The contribution of DSDP/ODP submarine basaltic glass collections, Phys. Earth Planet. Inter., 156, 223-241, doi:10.1016/j. pepi.2005.03.022.

Tauxe, L., A. T. Mullender, and T. Pick (1996), Pot-bellies, wasp-waists and superparamagnetism in magnetic hysteresis, J. Geophys. Res., 101, 571-583, doi:10.1029/95JB03041.

Thellier, E., and O. Thellier (1959), Sur l'intensité du champ magnétique terrestre dans le passé historique et géologique, Ann. Geophys., 15, 285-376.

Valet, J.-P. (2003), Time variations in geomagnetic intensity, Rev. Geophys., 41(1), 1004, doi:10.1029/2001RG000104.

van den Bogaard, P., and C. Schirnick (1995), ${ }^{40} \mathrm{Ar} /{ }^{39} \mathrm{Ar}$ laser probe ages of Bishop tuff quartz phenocrysts substantiate long-lived silicic magma chamber at Long Valley, United States, Geology, 23, 759-762, doi:10.1130/0091-7613 (1995)023<0759:AALPAO>2.3.CO;2.

Wilson, C. J. N., and W. Hildreth (1997), The Bishop Tuff: New insights from eruptive stratigraphy, J. Geol., 105, 407-439, doi:10.1086/515937.

Wilson, C. J. N., and W. Hildreth (2003), Assembling an ignimbrite: Mechanical and thermal building blocks in the Bishop Tuff, California, J. Geol., 111,653-670, doi:10.1086/378335.

Worm, H.-U., and M. Jackson (1999), The superparamagnetism of Yucca Mountain Tuff, J. Geophys. Res., 104, 25,415-25,425, doi:10.1029/1999JB900285.

Worm, H.-U., and H. Markert (1987), The preparation of dispersed titanomagnetite particles by the glass ceramic method, Phys. Earth Planet. Inter., 46, 263-269, doi:10.1016/00319201(87)90189-0.

York, D. (1968), Least squares fitting of a straight line with correlated errors, Earth Planet. Sci. Lett., 5, 320-324, doi:10.1016/S0012-821X(68)80059-7.

Yu, Y., and L. Tauxe (2005), Testing the IZZI protocol of geomagnetic field intensity determination, Geochem. Geophys. Geosyst., 6, Q05H17, doi:10.1029/2004GC000840.

Yu, Y., L. Tauxe, and A. Genevey (2004), Toward an optimal geomagnetic field intensity determination technique, Geochem. Geophys. Geosyst., 5, Q02H07, doi:10.1029/ 2003GC000630. 